\title{
The gene expression profiles of canine mammary cancer cells grown with carcinoma-associated fibroblasts (CAFs) as a co-culture in vitro
}

\author{
Magdalena Król ${ }^{1 *}$, Karol M Pawłowski ${ }^{1,2}$, Katarzyna Szyszko $^{1}$, Henryk Maciejewski ${ }^{3}$, Izabella Dolka ${ }^{4}$, \\ Elisabetta Manuali ${ }^{5}$, Michał Jank ${ }^{1}$ and Tomasz Motyl ${ }^{1}$
}

\begin{abstract}
Background: It is supposed that fibroblasts present in tumour microenvironment increase cancer invasiveness and its ability to metastasize but the mechanisms have not been clearly defined yet. Thus, the current study was designed to assess changes in gene expression in five various cancer cell lines grown as a co-culture with the carcinoma-associated fibroblasts (CAFs) in vitro.

Results: A carcinoma-associated fibroblast cell line was isolated from a canine mammary cancer. Then, a co-culture of cancer cells with the CAFs was established and maintained for $72 \mathrm{hrs}$. Having sorted the cells, a global gene expression in cancer cells using DNA microarrays was examined. The analysis revealed an up-regulation of 100 genes and a down-regulation of 106 genes in the cancer cells grown as a co-culture with the CAFs in comparison to control conditions. The PANTHER binomial statistics tool was applied to determine statistically over-manifested pathways $(p<0.05)$. Bulk of the up-regulated genes are involved in the adhesion, the angiogenesis, the epithelialmesenchymal transition (EMT) and generally take part in the developmental processes. These results were further confirmed using real-time qPCR. Moreover, a wound-healing assay and growth characteristics on Matrigel matrix showed that CAFs increase cancer cell migration and matrix invasion.

Conclusion: The results of the current study showed that the co-culturing of cancer cells and the CAFs caused significant changes to the cancer gene expression. The presence of the CAFs in a microenvironment of cancer cells promotes adhesion, angiogenesis and EMT.
\end{abstract}

\section{Background}

Since canine mammary tumours in bulk are of epithelial origin this kind of cells is subjected to many studies. Over the last few years it has also been pin-pointed that concomitant changes occur within stromal cells, which contribute to the tumour microenvironment as well $[1,2]$. Tumour microenvironment embraces inflammatory, fibroblastic, endothelial cells, adipocytes and other. Changes within these stromal cells have been postulated to increase the tumorigenic phenotype of the epithelial cell, promote malignant transformation, induce epithelial-mesenchymal transition (EMT) and promote tumour

\footnotetext{
* Correspondence: magdalena_krol@sggw.pl

'Department of Physiological Sciences, Faculty of Veterinary Medicine, Warsaw University of Life Sciences - WULS, Nowoursynowska 159, 02-776

Warsaw, Poland

Full list of author information is available at the end of the article
}

spreading and metastasis [3]. It is worth noting however, that in almost all the tumours, the main cell type of cancer stromal compartment is fibroblast. These cells are usually atypical and are termed carcinoma-associated fibroblasts (CAFs). We assume there is a cross-talk between the tumour cells and the CAFs, which promotes migratory, and invasive properties of cancer cells [3] though their exact role within cancer microenvironment has not been fully defined yet. Thus, the study was conducted to assess the changes in gene expression in cancer cells grown as a co-culture with the CAFs in vitro. As far as we know the study presented hereby is a pioneering microarray experiment in this field. Despite that our study involved five various cell lines, only one CAFs cell line was used, thus the results may be limited to this particular CAF model. Further studies in this field are required. 
The analysis revealed an up-regulation within a span of 100 genes and a down-regulation within 106 genes in cancer cells grown as a co-culture with the CAFs, comparing against set control conditions. In this manuscript we focused mainly on the gene sets involved in adhesion, developmental process and neurotransmissions.

The results of our study can be extrapolated on human research because canine mammary tumours are being considered a spontaneous animal model of human breast cancer [4]. There are many similarities between human and canine mammary cancers: in both species they represent a heterogeneous group in terms of morphology and biological behaviour [5], in both similar cancer-related pathways are activated [6-8] as much as both species live under similar environmental conditions.

\section{Methods \\ Cell lines}

The cell lines used for this study have previously been given an account of [9-12]. Two canine mammary adenocarcinoma cell lines (CMT-W1, CMT-W2), an anaplastic cancer cell line (P114), a simple carcinoma cell line (CMT-U27) and a spindle-cell mammary tumour cell line (CMT-U309) were examined. The CMT-W1 and the CMT-W2 cell lines had kindly been donated by Prof. Dr. Maciej Ugorski and Dr. Joanna Polanska from Wroclaw University of Environmental and Life Sciences (Poland). The CMT-U27 cell line had kindly been donated by Dr. Eva Hellmen from Swedish University of Agricultural Sciences (Sweden) and the P114 cell line had kindly been donated by Dr. Gerard Rutteman from Utrecht University (The Netherlands).

The cells were cultured under optimal conditions: a medium (RPMI-1640) enriched with 10\% (v/v) heatinactivated fetal bovine serum (FBS), penicillin-streptomycin (50 iU mL-1), and fungizone (2.5 mg mL-1) (reagents obtained from Sigma Aldrich, USA), in an atmosphere of $5 \% \mathrm{CO} 2$ and $95 \%$ humidified air at $37^{\circ} \mathrm{C}$, and routinely sub-cultured every other day. The methods of canine mammary cancer cells culturing have previously been given an account of [9-12].

\section{Tumour sample}

A mammary tumour was surgically removed during mastectomy on a 12 years old mixed breeds female. The tumour then, was divided into equal halves, one of them was fixed in $10 \%$ neutral buffered formalin and routinely embedded in paraffin to perform histological assay. The other, was used to isolate and establish a carcinomaassociated fibroblast cell line.

\section{Carcinoma-associated fibroblasts isolation}

The cells isolation from cancer tissue has been described in our previous manuscript [13]. The tumor sample was collected into the medium RPMI 1640 (Sigma Aldrich, USA) containing flask immediately after mastectomy. The RPMI 1640 medium had been used to maintain the same culturing conditions for mono- and co-culture. The tumour sample was then sliced and cultured overnight in collagenase containing medium RPMI 1640 according to the Limon et al. [14] protocol (modified by Dr Eva Hellmen, Swedish University of Agricultural Sciences, Sweden). The following day, the medium was centrifuged and pellet was suspended in a fresh culture medium supplemented in FGF $(10 \mathrm{nM} / \mathrm{ml}$, obtained from Sigma Aldrich, USA), a medium that encourages preferential fibroblastic outgrowth.

\section{Histopathological examination}

The tissue sample embedded in paraffin block was cut into five $\mu \mathrm{m}$ sections and baked in $37^{\circ} \mathrm{C}$ overnight. After dewaxing in xylene and rehydration in ethanol, for antigen retrieval, the slides were placed in $0.02 \mathrm{M}$ citrate buffer, pH 6.0 and boiled in the decloaking chamber. The tumor type was classified based on the World Health Organization (WHO) Histological Classification and Mammary Tumors of the Dog and Cat classification $[15,16]$. The mammary carcinoma grading was assessed in respect to tubule formation, degree of differentiation and mitotic index.

The carcinoma-associated fibroblasts and the canine mammary cancer cells were cultured on Lab-Tek (Nunc Inc., USA) 4-chamber culture slides and were then fixed with ethanol after the 24 hrs.

The immunohistochemical examination of expression of Ki67, cytokeratin, vimentin, smooth muscle actin, s100 protein, p63 protein was performed on the tissue sample as well as on carcinoma-associated fibroblasts to confirm the origin of cell culture. The MUC1 expression was analyzed in the canine mammary cancer cell lines.

The samples were incubated in the Peroxidase Blocking Reagent (Dako, Denmark) for $10 \mathrm{~min}$ at room temperature prior to the antibody incubation. After $30 \mathrm{~min}$ incubation in 5\% bovine serum albumin (Sigma Aldrich, Germany), the following primary antibodies were used (diluted in 1\% bovine serum): mouse monoclonal antiKi67 (Clone MIB-1) at the concentration 1:75; monoclonal mouse anti-human cytokeratin (Clone MNF116) at the concentration 1:50; monoclonal mouse anti-human vimentin (Clone Vim 3B4) at the concentration 1:50; monoclonal mouse anti-human actin (Clone HHF35) at the concentration 1:50; polyclonal rabbit anti-S100 (ready to use solution) all obtained from Dako (Denmark); monoclonal mouse anti-p63 protein (Santa Cruz Biotechnology, USA) and monoclonal mouse antiMUC1 (Abcam, United Kindgdom) at the concentration $1: 10$. According to the manufacturer's instructions the slides were incubated with antibodies at $+4^{\circ} \mathrm{C}$ overnight 
or $1 \mathrm{hr}$ at room temperature. For the staining the antimouse or anti-rabbit EnVision kits (Labelled Polymers consist of secondary anti-rabbit antibodies conjugated with the HRP enzyme complex obtained from Dako) were used. To develop the coloured product, the 3,3'Diaminobenzidine (DAB) substrate was used (Dako). Finally, the haematoxylin was used for nuclei counterstaining.

For each immunohistochemical analysis as the negative control, the staining without the use of primary antibodies was done. The pictures were taken using Olympus microscopy BX60 (Olympus, Germany).

\section{Co-culture and sorting}

The CAFs $\left(10^{5}\right.$ cells $)$ were grown on $75 \mathrm{~cm}^{2}$ culture flasks and the cancer cells (CMT-W1, CMT-W2, CMTU27, CMT-U309, P114) were layered ( $5 \times 10^{5}$ cells $)$ on the top of the CAFs (fibroblasts and cancer cells at 1:5 ratio [17]). An Orange CellTracker fluorescent dye CMTMR (Invitrogen, USA) was used to stain the CAFs' population before the cancer cell population was added. Initially, optimal staining conditions were determined by incubating CAFs in various concentrations of CMTMR (5-25 $\mu \mathrm{M}$ dye, according to the manufacturer's instructions) and checking the fluorescence signal after $72 \mathrm{hrs}$ using FACS. The lowest concentration that gives positive results has been used in further experiments (5 $\mu \mathrm{M})$. Staining was accomplished by incubation in serum/antibiotics-free RPMI medium containing $5 \mu \mathrm{M}$ CMTMR (10 mM stock in DMSO; Sigma Aldrich, USA) for $45 \mathrm{~min}$ at $37^{\circ} \mathrm{C}$. Subsequently, the medium was aspirated, and the CAFs were washed with PBS twice and incubated with complete RPMI for $1 \mathrm{hr}$ and then again washed to remove any remnant non-metabolized CMTMR. The cancer cells were placed on the CMTMR-stained CAFs.

The co-culture was maintained for 72 hrs. Then, the cells were harvested by trypsynization, analyzed and sorted using FACS Aria II high speed cell sorter with Diva 5.0 software (Becton Dickinson, USA). Based on the FSC and SSC cytogram, live cells were gated to exclude all dead cells, cell debris and cell clumps. Within the gated cell populations, fluorescing cells were identified as CMTMR-labelled carcinoma-associated fibroblasts and non-fluorescent as cancer cells. Excitation wavelength used was $488 \mathrm{~nm}$, whereas emission wavelength used was $578 \mathrm{~nm}$. Cancer cells were sorted into RPMI 1640 medium in $15 \mathrm{ml}$ polypropylene tubes (BD Biosciences).

\section{Confocal microscopy}

The CAFs grown as a mono-culture were stained using Orange CellTracker fluorescent dye CMTMR, as described above. The cells grown on plastic were fixed in $70 \%$ ethanol (10 $\mathrm{min})$, washed in PBS three times and the coverslips were mounted on microscope slides using ICN mounting medium. The cell imaging was performed on confocal laser scanning microscope FV-500 system (Olympus Optical Co, Germany) after $1 \mathrm{hr}$, then after $72 \mathrm{hrs}$ after the staining. The excitation/emission were: HeNe $543 \mathrm{~nm}$ laser with $610 \mathrm{~nm}$ filter for CMTMR staining. The cells were examined using the Fluoview program (Olympus Optical Co., Germany). The pictures have been analyzed using a computerassisted image analyzer (Olympus Microimage ${ }^{\mathrm{TM}}$ Image Analysis, software version 4.0 for Windows, USA).

\section{Wound-healing assay}

To assess the migration ability of cancer cells grown as a co-culture with CAFs, we applied a wound-healing test. The cancer cells (grown as the co-culture with CAFs at the 5:1 ratio, and normal control cells) were separately seeded in multi-well plates and then, (after 72 hrs when the cells were confluent) using a pipette tip $(100 \mathrm{ul})$ a straight scratch had been made, simulating a wound. The images were captured at the beginning and at regular intervals (after 2, 4 and 6 hours) during cell migration to close the wound. The images then were compared to quantify the cells' migration rate. This method is particularly suitable for studies of cell-cell interaction on cell migration [18]. The pictures have been analyzed using a computer-assisted image analyzer (Olympus Microimage ${ }^{\mathrm{TM}}$ Image Analysis, software version 4.0 for Windows, USA).

\section{D culture}

Cancer cells were treated with trypsin and resuspended in culture medium. $35 \mathrm{~mm}$ culture plates (Corning Inc.) were coated with $100 \mu \mathrm{l}$ of growth factor reduced Matrigel (BD Biosciences) and left to solidify for $30 \mathrm{~min}$. at $37^{\circ} \mathrm{C}$. The control cells were then plated at a concentration of $10^{4}$ cells $/ \mathrm{ml}$. Co-cultured cells were plated at the same concentration (cancer cells and CAFs at 5:1 ratio). The growth of cells on Matrigel was observed everyday under phase-contrast microscope (Olympus).

\section{Microarray analysis}

The sorted cancer cells grown as a co-culture were centrifuged (2,500 rpm for $5 \mathrm{~min})$, whereas cancer cells grown as mono-cultures were washed with PBS and harvested by trypsynization and centrifuged $(2,500 \mathrm{rpm}$ for $5 \mathrm{~min})$. The total RNA from the samples was isolated using a Total RNA kit (A\&A Biotechnology, Poland) according to the manufacturer's protocol. The isolated RNA samples were dissolved in RNase-free water. The quantity of the isolated RNA was measured using NanoDrop (NanoDrop Technologies, USA). The samples with adequate amounts of RNA were treated with DNaseI to 
eliminate DNA contamination. The samples were subsequently purified using RNeasy MiniElute Cleanup Kit (Qiagen, Germany). Finally the RNA samples were analyzed on a BioAnalyzer (Agilent, USA) to measure the final RNA quality and integrity.

The total RNA $(10 \mu \mathrm{g})$ of each cell line was reversetranscribed using SuperScript Plus Direct cDNA Labeling System, (Invitrogen, USA) according to the manufacturer's protocol for each microarray slide. Singlestrand cDNAs were stained with Alexa 647 and Alexa 555 (Invitrogen). Dog-specific oligonucleotide microarray slides Canis familiaris V1.0.1 AROS (Operon, USA) with 25,383 probes were used for the hybrydization. Hybridization was performed using automatic hybridization station HybArray12 (PerkinElmer, USA). Two replicates were made (dye-swap).

The slides were analyzed using microarray scanner ScanArray HT and ScanExpress software (PerkinElmer, USA).

\section{Real-time qPCR}

The mRNA sequences of the key genes were obtained from NCBI database. Primers were designed using PRIMER3 software (free on-line access) and checked using Oligo Calculator (free on-line access) and Primer-Blast (NCBI database). Primers' sequences are listed in Table 1. HPRT and RPS19 genes were used as non-regulated reference genes for normalization of target gene expression $[19,20]$. Quantitative RT-PCR was performed using fluorogenic Lightcycler Fast Strand DNA Sybr Green (Roche) and the Light Cycler (Roche). The results were analyzed using comparative $\mathrm{Ct}$ method [21]. Relative transcript abundance of the gene equals $\Delta \mathrm{Ct}$ values $\left(\Delta \mathrm{Ct}=\mathrm{Ct}^{\text {reference }}-\mathrm{Ct}^{\text {target }}\right)$. Relative changes in transcript are expressed as $\Delta \Delta C t$ values $\left(\Delta \Delta C t=\Delta C t^{\text {co-cul- }}\right.$ ture $\left.-\Delta C t^{\text {control }}\right)$. The experiment was conducted three times.

\section{Statistical analysis}

In the analysis of differential gene expression, background-corrected value of signal in each microarray channel was used. Prior to the analysis, non-specific filtering was performed, i.e. genes with small level of expression were removed (we set an arbitrary threshold according to which at least half of the samples' expression was to be at least 100). This reduced the number of genes down to 24842 . Then the $\log 2$ ratio of the sample vs control channels was calculated and the signal was loes normalized. Quality control, including MA analysis, and signal normalization were done with the Bioconductor software. The analysis of differential expression was performed using linear methods for microarrays (limma package in Bioconductor software) [22]. The method tests the null hypothesis of no differential expression between the sample and control groups using the moderated t-statistic [22], which has similar interpretation as the ordinary $t$-test statistic. We identified 206 genes with the p-value below 0.05 and fold change $>2.0$.

The microarray data discussed in this publication has been deposited in NCBI's Gene Expression Omnibus and is freely accessible through GEO Series accession number GSE29601.

The gene function was identified using the NCBI database and PANTHER pathway analysis software [23]. The pathway analyses were conducted using binominal statistic test (PANTHER) with the cut-off value $p<0.05$.

The statistical analysis of optical density, wound healing assay and Real-time qPCR was conducted using Prism version 5.00 software (GraphPad Software, USA). The one-way ANOVA, and ANOVA + Tukey HSD (Honestly Significant Difference) post-hoc test as well as $t$-test were applied. The $\mathrm{p}$-value $<0.05$ was regarded as significant whereas $\mathrm{p}$-value $<0.01$ and $\mathrm{p}$-value $<0.001$ as highly significant.

\section{Results}

\section{Tumor sample and CAFs examination}

The histopathological and immunohistochemical assessment of the tissue sample, from which the carcinomaassociated fibroblasts were isolated, showed that the tumour type was a complex carcinoma of the $1^{\text {st }}$ grade malignancy (Figure 1a). The histopathological and immunohistochemical analysis of the isolated cells

Table 1 Primers used for Real-time qPCR

\begin{tabular}{lllll}
\hline Gene symbol & Forward primer & Reverse primer & Optimum annealing temp. $\left({ }^{\circ} \mathrm{C}\right)$ & Optimum annealing time $(\mathbf{s e c})$ \\
\hline DSP & CAGACTCACCGAAGAGGAAA & CTGCTGTGAAGCTGGGAGT & 61 & 7 \\
\hline MAG & TGCCATCGTCTGCTACATTA & CAGTCGCCTCTCACTCTCAT & 60 & 6 \\
\hline PCDH19 & CTITCACATCACTGCACTCG & GTGTGTGGGAGGTGAGTC & 61 & 6 \\
\hline HPRT & AGCTTGCTGGTGAAAAGGAC & TTATAGTCAAGGGCATATCC & 59 & 6 \\
\hline RPS19 & CCTTCCTCAAAAAGTCTGGG & GTTCTCATCGTAGGGAGCAAG & 61 & 10 \\
\hline
\end{tabular}

Primers sequences used in this study and their annealing optimal temperature and time. The mRNA sequences of key genes were obtained from NCBI database. Primers were designed using PRIMER3 software (free on-line access) and checked using Oligo Calculator (free on-line access) and Primer-Blast (NCBI database). HPRT and RPS19 genes were used as non-regulated reference genes for normalization of target gene expression $[19,20]$. 


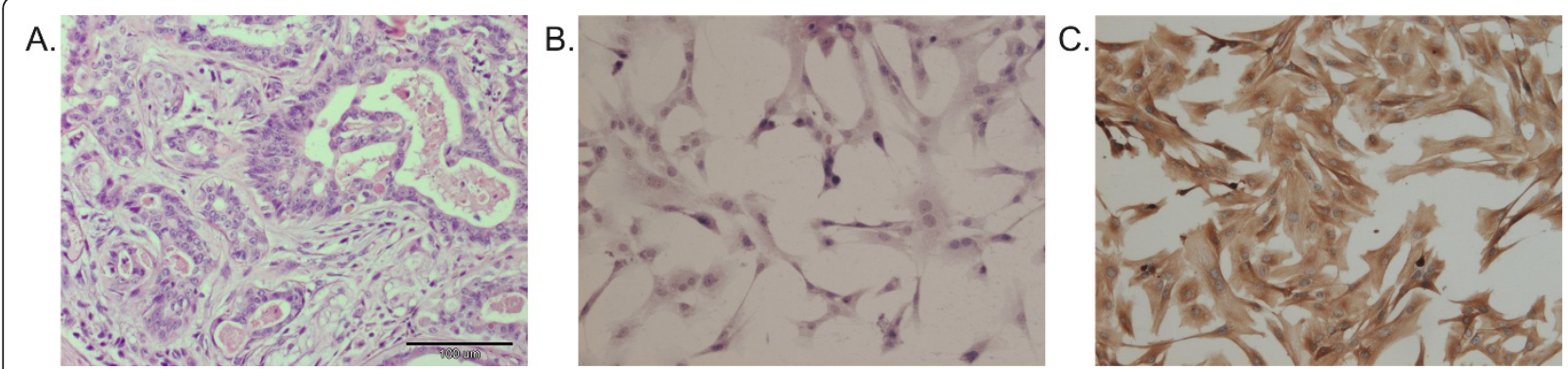

Figure 1 Cancer associated fibroblasts isolated from canine mammary cancer. Representative pictures of A. Canine mammary complex carcinoma (HE staining) tissue from which the carcinoma-associated fibroblasts were isolated. B. The culture of carcinoma-associated fibroblasts (CAFs) isolated from the canine mammary complex carcinoma (HE staining) and C. Carcinoma-associated fibroblasts (CAFs) isolated from canine complex mammary carcinoma revealed a strong vimentin expression (brown color). The pictures were obtained using Olympus BX60 microscope (at the magnification of 200x).

(Figure $1 \mathrm{~b}$ ) revealed that the cell line did not express cytokeratin, S100 protein, p63 protein and actin, whereas a strong vimentin expression was detected (at the level of 3 in $0-3$ scale) (Figure 1c). The analysis confirmed that the isolated cell line is an atypical colony of fibroblasts which are termed the CAFs.

\section{Sorting of the co-cultured cells}

The Flow-Cytometry easily distinguished the CMTMRstained cells from the unstained ones (Figure 2a) and allowed the proper further sorting of each population (Figure 2b, c). The co-culture was maintained for $72 \mathrm{hrs}$. According to the manufacturer's instruction, CMTMR probes remain vividly fluorescent for at least $72 \mathrm{hrs}$ after incubation in fresh medium at $37^{\circ} \mathrm{C}$ and through at least four cell divisions. The confocal observations confirmed that after $72 \mathrm{hrs}$ of the staining with the CMTMR all the cells showed red-staining cytoplasm pattern (Figure 2c, d, e). No detrimental effects on proliferation and plating efficiency was observed. Our analysis of optical density of the red dye in the cells measured $1 \mathrm{hr}$ and $72 \mathrm{hrs}$ after the staining showed very similar results (any statistically significant difference had not been found) (Figure 2f). It indicates that there wasn't any staining loss, thus we suppose that the dye wasn't leaking from CAFs to stain cancer cells. It had been also suggested in the subject literature [24]. Moreover, confocal microscopy analysis of the red dye fluorescence with Nomarski Interferenced Contrast showed that all of the stained CAFs maintained their staining pattern after the $72 \mathrm{hrs}$. Thus, the artificial sorting of unstained CAFs as cancer cells is not very probable. Our FACS sorting isolated a $97-99 \%$ pure population on postsort (assessed by BC FACS Diva 5.0 software) what was checked by FACS (Figure 2b, c) and fluorescence microscopy (data not shown). Previously published study of the human fibroblasts and epithelial cells sorting based on the cell tracker staining showed similar results [25].

\section{Migration assay and growth characteristics on Matrigel matrix}

The wound healing assay showed that in all the cancer cell lines the co-culturing with CAFs increased their migratory abilities (Figure 3). CMT-U27 cells grown with CAFs almost completely closed the wound (99\%) in 6 hours, whereas CMT-U27 control cells after 6 hrs closed $68 \%$ of the wound. Similarly, CMT-U309 and P114 cells (grown with CAFs) after 6 hrs completely closed the wound (100\%), whereas control cells closed only $55 \%$ and $50 \%$ (respectively) of the wound. CMTW1 cells grown with CAFs completely closed the wound after 4 hrs, whereas CMT-W1 control cells after $6 \mathrm{hrs}$ (after $4 \mathrm{hrs} 64 \%$ of the wound was closed). CMTW2 cells grown with CAFs closed $93 \%$ of the wound after 6 hrs, whereas control cells closed only $52 \%$ of the wound.

To assess the ability of the cell lines to matrix invasion, we have assessed their growth characteristics on Matrigel matrix (Figure 4). After $72 \mathrm{hrs}$ of culturing (similarly as in all experiments) on Matrigel CMT-U27, CMT-U309 and P114 cell lines formed colonies, whereas CMT-W1 and CMT-W2 cell lines formed branching structures (Figure $4 \mathrm{a}$ ) what indicated their invasive phenotype. However, all the cell lines grown as a co-culture with CAFs after 72 hrs were dispersed (Figure $4 \mathrm{~b}$ ) what indicated increase of their matrix invasion ability by CAFs.

\section{Gene expression analysis}

The gene expression analysis showed similar rate of gene expression in each of the dye-swap experiment. This result indicates that all microarray samples were successfully labeled, hybridized, and scanned. The discriminating analysis (with $\mathrm{p}$ value cut-off $<0.05$; fold change $>2.0$ ) revealed 106 up-regulated (Table 2) and 100 down-regulated (Table 3) genes in cancer cells grown as a co-culture with the CAFs in each of the 


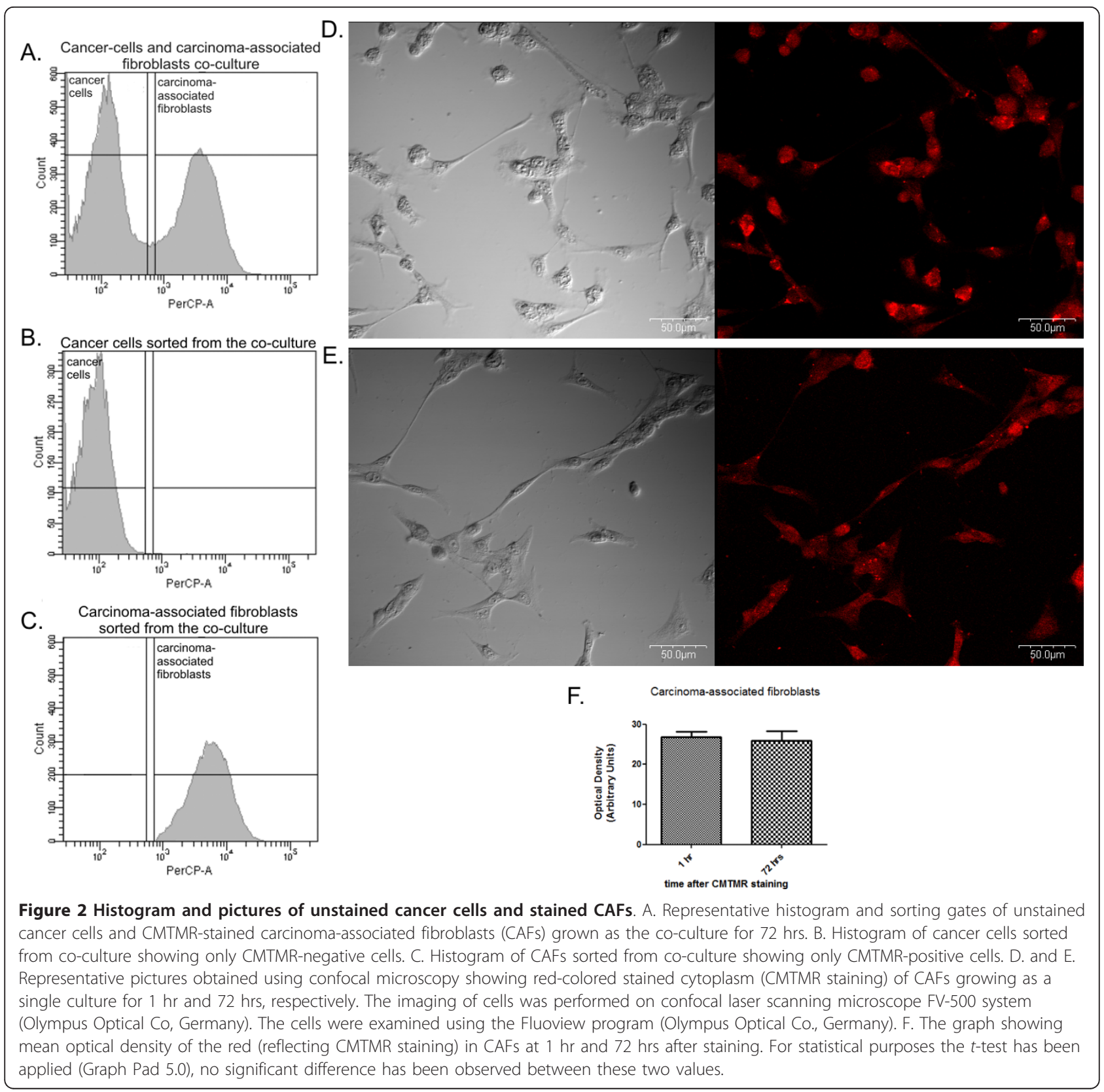

slides. These up/down-regulated genes were common for each cell line examined individually, compared to the same cell line grown as a mono-culture. Thus, these genes were activated/inactivated in all of the cell lines under co-culture conditions with the CAFs.

The PANTHER binomial statistics tool to compare classifications of multiple clusters of lists to a reference list of Canis familiaris genes allowed us to statistically determine over-manifestation of PANTHER biological process and pathways classification categories. The PANTHER biological process analysis revealed that most of the up-regulated genes in cancer cells grown as a co-culture with the CAFs were involved in: cell surface receptor linked signal transduction $(p=9.05 \mathrm{E}-03)$, lysosomal transport $(p=9.2 \mathrm{E}-03)$, developmental process $(p$ $=3.64 \mathrm{E}-02)$, antigen processing and presentation $(p=$ $4.22 \mathrm{E}-02)$, signal transduction $(p=4.35 \mathrm{E}-02)$, cell communication $(p=4.55 \mathrm{E}-02)$, nervous system development ( $p=$ 4.97E-02).

Because our concern involved interactions between cancer cells and carcinoma associated fibroblasts which could predispose cancer to metastasis, we specifically focused on the up-regulated genes involved in cell adhesion and cellular morphogenesis: QRICH2, CHAD, 

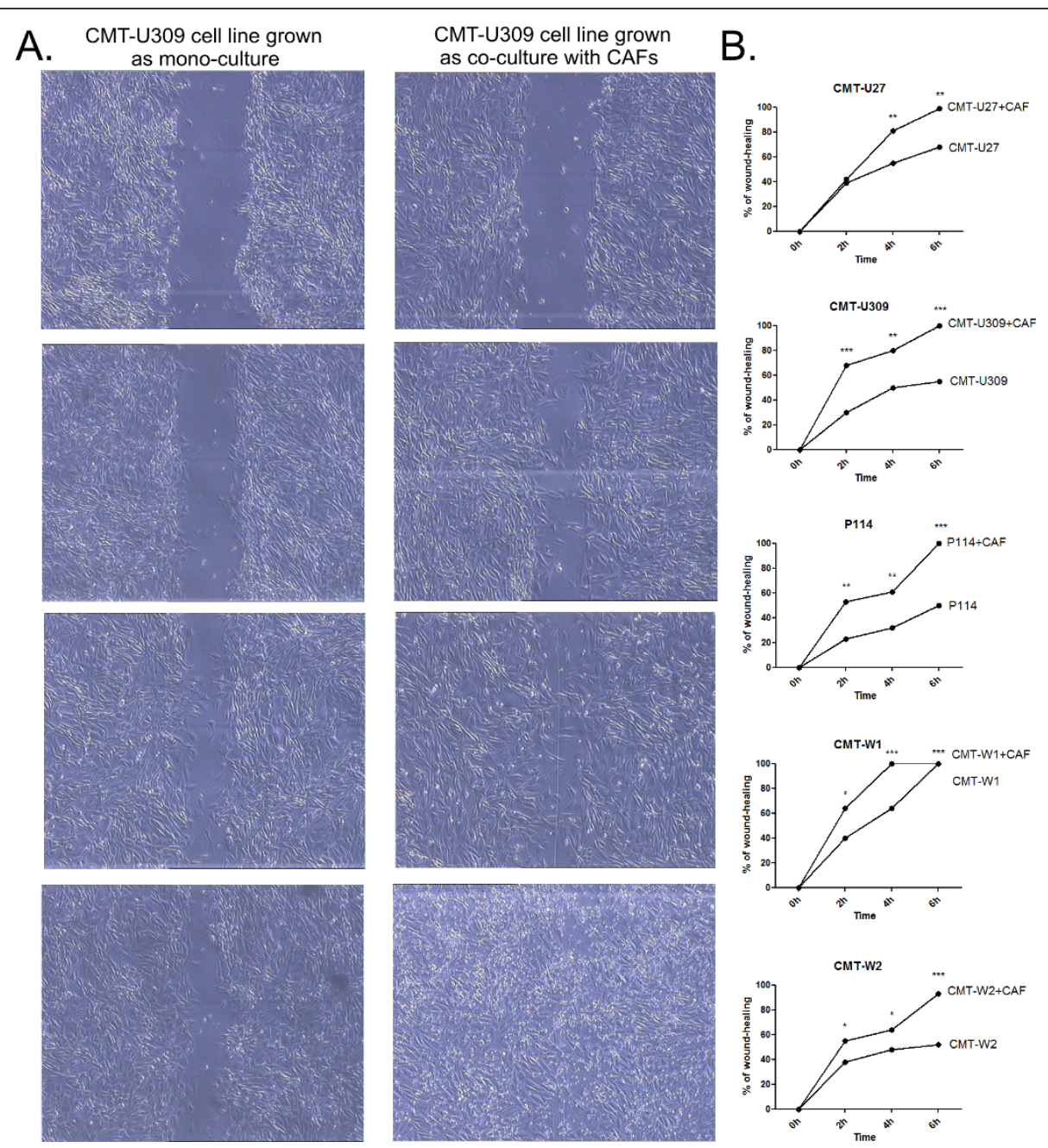

Figure 3 Wound healing assay of canine mammary cancer cells grown in control conditions and as a co-culture with CAFs. A Representative pictures of migration (wound closing) of CMT-U309 cell line grown as a mono-culture and co-culture with CAFs at 0, 2, 4 and 6 hrs after the scratch was made. B The graphs of \% of wound closure after the 2, 4 and 6 hrs of migration. The pictures were taken using phasecontrast microscopy (Olympus) at the magnification of 100x. The statistical analysis was performed using Prism version 5.00 software (GraphPad Software, USA). The one-way ANOVA was applied to analyze the results. $p<0.05$ was regarded as significant and marked as ${ }^{*}$, whereas $p<0.01$ and $p<0.001$ were regarded as highly significant and marked as ** and ${ }^{* * *}$, respectively.

FOXQ1, PCSK6, CLEC7A, SH3BP1, NEFM, PCDH19, LPHN2, DSP, KTN1, VCAM1, MAG, and PTPN6 (Table 2). Interestingly, the gene expression analysis also revealed an up-regulation of 24 genes involved in developmental processes such as: a mammary gland development, a mesoderm development, an ectoderm development, a skeletal system development, a nervous system development, an embryonic development, a heart development, and a muscle-organ development. The pathway analysis revealed that significantly overmanifested were: the salvage pyrimidine ribonucleotides ( $p=02.87 \mathrm{E}-03)$, the oxytocin receptor mediated signaling pathway ( $p=4.76 \mathrm{E}-03)$, the thyrotropin-releasing hormone receptor signaling ( $p=5.21 \mathrm{E}-03)$, the 5HT2 type receptor mediated signaling pathway $(p=6.99 \mathrm{E}$ -
$03)$, the metabotropic glutamate receptor III ( $p=8.14 \mathrm{E}-$ $03)$, the metabotropic glutamate receptor group II $(p=$ $3.33 \mathrm{E}-02)$, the metabotropic glutamate receptor I ( $p=$ $1.75 \mathrm{E}-02)$, the Beta 2 and Beta1 adrenergic receptor signaling ( $p=2.54 \mathrm{E}-02)$ and the histamine $\mathrm{H} 1$ receptor mediated signaling $(p=2.87 \mathrm{E}-02)$.

Among the down-regulated genes no significant pathways or biological processes and their over-manifestation were found (Table 3) comparing to a reference list of Canis familiaris genes.

The results were confirmed at mRNA level using real-time qPCR analysis

For the purposes of the microarray data validation, we have randomly selected 3 of all the genes that may play 

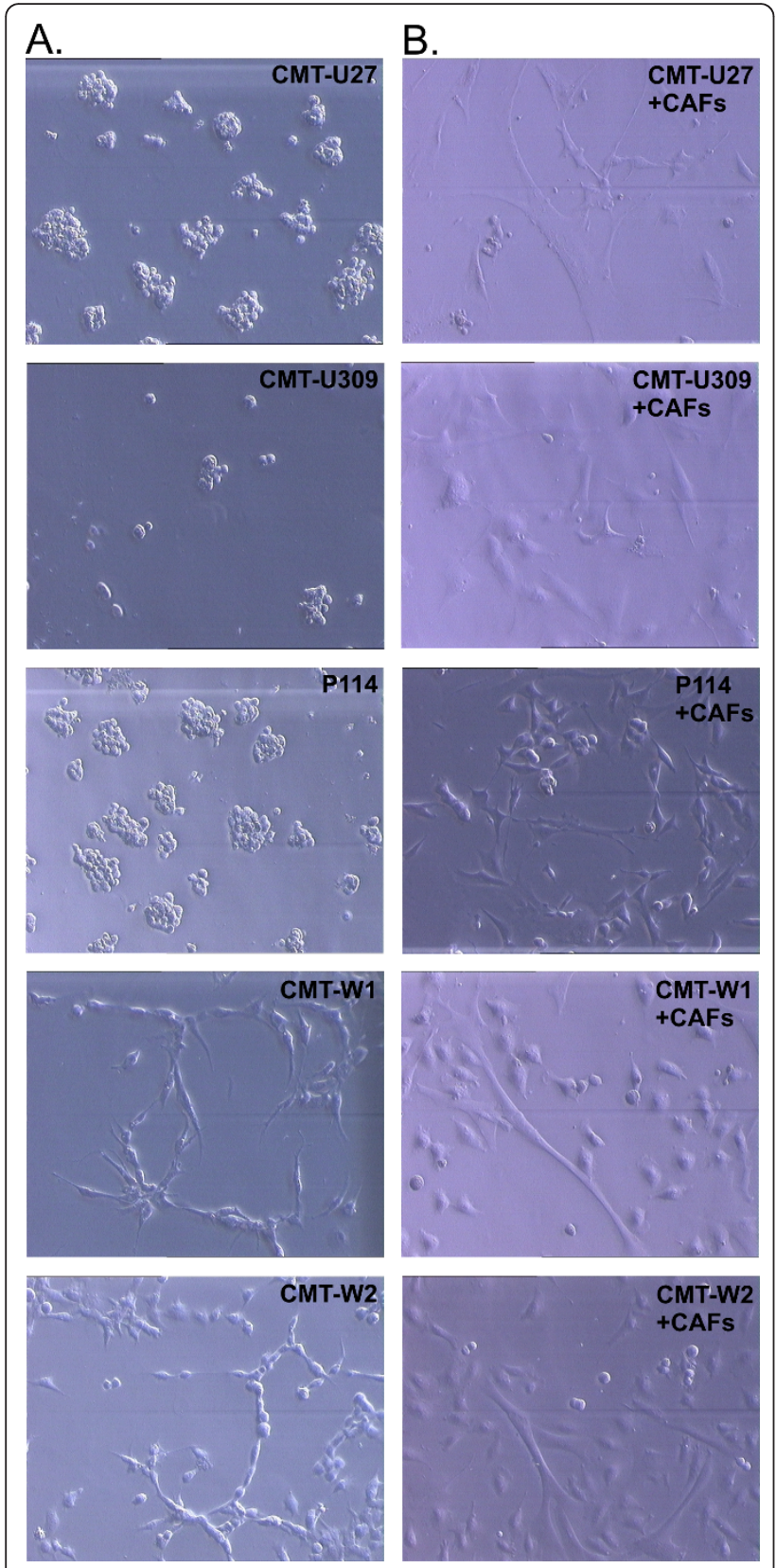

Figure 4 Canine mammary cancer cell lines growth characteristics in Matrigel matrix. A Growth characteristics of CMT-U27, CMT-U309, P114, CMT-W1 and CMT-W2 cell lines (phase contrast micrographs) grown on Matrigel matrix for 72 hours. B Growth characteristics of CMT-U27, CMT-U309, P114, CMT-W1 and CMT-W2 cell lines (phase contrast micrographs) grown as a coculture with CAFs on Matrigel matrix for 72 hours. The pictures were taken using phase-contrast microscopy (Olympus) at the magnification of $200 x$

the most important role in the cancer cells-CAFs interactions: PCDH19, DSP and MAG. Real-time qPCR results showed similar trends in gene expression changes as were observed in microarray studies (Figure 5).

\section{MUC1 expression detection in cancer cell lines}

Because the MAG gene up-regulation was found in cancer cells grown as a co-culture with the CAFs, the expression of MUC1 (which binds MAG) was examined immunohistochemically (Figure 6). The MUC1 expression was confirmed in all of the examined cell lines.

\section{Discussion}

Canine mammary cancers in bulk arise from epithelial cells. Several genetic alterations have been detected, that may predispose these cells to the malignant transformation [10-12]. However, researches over the last few years suggested that concomitant changes also occur in stromal cells that form the tumour microenvironment $[1,2]$. The hypothesis of stromal cells involvement in tumorigenesis is based on a study of embryological development where interactions between various cells are necessary for programming and maintaining epithelial structure and function. The embryonic epithelial and stromal cells of mesenchymal origin engage in a molecular dialogue that ensures the proper organ development and function [3].

The study showed in cancer cells after a co-culture with CAFs an up-regulation of 23 genes (Table 2) involved in developmental processes (a nervous system development, an embryonic development, a mesoderm and ectoderm development).

The involvement of fibroblasts in the malignant transformation of epithelial cells has previously been documented [3,26-28]. Moreover, the histology and growth characteristics of CAFs were found different from those of the fibroblasts associated with normal epithelial cells [3]. Mishra et al. [29] have proposed bidirectional crosstalk between the CAFs and the cancer cells which release proteins that increase the fibroblasts ability to secrete a variety of tumour-promoting factors, which then act back on the malignant cells to change their gene expression and promote their proliferative, migratory, and invasive properties. On the other hand, other studies showed that only direct contact of fibroblasts with cancer cells is able to cause changes in their gene expression and biology [30-32].

So far several papers have been published about gene expression in tumour microenvironment. Most of them describe gene expression in fibroblasts, but not in cancer cells, however there are some papers available about the changes in gene expression in cancer cells [33-36]. These reports indicated up-regulation of genes involved in angiogenesis, EMT and migration in cancer cells grown with fibroblasts. Surprisingly, some of the genes identified, even though functionally identical turned out to be of different names. The studies have been conducted using various cancer models (various species) and various cell lines, so the differences are possible. 
Table 2 Up-regulated genes in cancer cells grown as a co-culture with CAFs

\begin{tabular}{lllll}
\hline No & $\begin{array}{l}\text { Fold } \\
\text { change }\end{array}$ & Gene ID & Gene name & Molecular function \\
\hline 1 & 4.18 & TRIM6 & $\begin{array}{l}\text { Tripartite motif-containing } \\
\text { protein } 6\end{array}$ & $\begin{array}{l}\text { ubiquitin-protein ligase activity; structural } \\
\text { constituent of cytoskeleton; RNA binding; } \\
\text { cytoskeletal protein binding }\end{array}$ \\
& & &
\end{tabular}

Biological process

spermatogenesis; neurotransmitter secretion; intracellular protein transport; exocytosis; cell cycle; signal transduction; synaptic transmission; carbohydrate metabolic process; protein metabolic process; cell-cell signaling; dorsal/ventral axis specification; mesoderm development; mammary gland development

\begin{tabular}{|c|c|c|c|c|c|}
\hline 2 & 3.76 & PPP1R12A & $\begin{array}{l}\text { Protein phosphatase } 1 \\
\text { regulatory subunit } 12 \mathrm{~A}\end{array}$ & $\begin{array}{l}\text { protein binding; phosphatase regulator } \\
\text { activity }\end{array}$ & protein metabolic process \\
\hline 3 & 3.73 & TCHHL1 & Trichohyalin-like protein 1 & & \\
\hline 4 & 3.24 & QRICH2 & Glutamine-rich protein 2 & receptor activity & fertilization; cell adhesion \\
\hline 5 & 3.14 & TMEM82 & Transmembrane protein 82 & & \\
\hline 6 & 3.14 & ZNF212 & Zinc finger protein 212 & DNA binding; transcription factor activity & $\begin{array}{l}\text { nucleobase, nucleoside, nucleotide and } \\
\text { nucleic acid metabolic process }\end{array}$ \\
\hline 7 & 3.13 & PYROXD1 & $\begin{array}{l}\text { Pyridine nucleotide- } \\
\text { disulfide oxidoreductase } \\
\text { domain-containing protein } \\
1\end{array}$ & oxidoreductase activity & $\begin{array}{l}\text { immune system process; respiratory electron } \\
\text { transport chain; apoptosis; ferredoxin } \\
\text { metabolic process; oxygen and reactive } \\
\text { oxygen species metabolic process }\end{array}$ \\
\hline 8 & 3.10 & PDE5A & $\begin{array}{l}\text { cGMP-specific 3','5'-cyclic } \\
\text { phosphodiesterase }\end{array}$ & hydrolase activity, acting on ester bonds & $\begin{array}{l}\text { visual perception; sensory perception; signal } \\
\text { transduction; nucleobase, nucleoside, } \\
\text { nucleotide and nucleic acid metabolic } \\
\text { process; signal transduction }\end{array}$ \\
\hline 9 & 3.02 & CHAD & Chondroadherin & receptor activity & $\begin{array}{l}\text { immune system process; cell surface } \\
\text { receptor linked signal transduction; cell-cell } \\
\text { adhesion; mesoderm development; skeletal } \\
\text { system development }\end{array}$ \\
\hline
\end{tabular}

$10 \quad 3.00 \quad$ QSER1 Glutamine and serine-rich
protein 1

$112.96 \quad$ PRKX $\quad$ Serine/threonine-protein kinase activity
kinase

\begin{tabular}{lllll}
\hline 12 & 2.90 & ZFAND5 & $\begin{array}{l}\text { AN1-type zinc finger } \\
\text { protein 5 }\end{array}$ & nucleic acid binding \\
\hline 13 & 2.86 & C2CD3 & $\begin{array}{l}\text { C2 domain-containing } \\
\text { protein 3 }\end{array}$ \\
\hline 14 & 2.82 & CEP110 & $\begin{array}{l}\text { Centriolin;Centrosomal } \\
\text { protein of 110 kDa }\end{array}$ \\
\hline 15 & 2.80 & FOXQ1 & Forkhead box protein Q1 & DNA binding; transcription factor activity
\end{tabular}

\begin{tabular}{llll}
\hline 16 & 2.80 & NUP210L & $\begin{array}{l}\text { Nuclear pore membrane } \\
\text { glycoprotein 210-like }\end{array}$ \\
\hline $17 \quad 2.79 \quad$ SLC22A11 & $\begin{array}{l}\text { Solute carrier family 22 } \\
\text { member } 11\end{array}$
\end{tabular}

ATPase activity, coupled to transmembrane movement of substances; ligase activity; carbohydrate transmembrane transporter activity; cation transmembrane transporter activity

muscle contraction; neurological system process; mitosis; intracellular signaling cascade; protein metabolic process; signal transduction;

sensory perception; respiratory electron transport chain 
Table 2 Up-regulated genes in cancer cells grown as a co-culture with CAFs (Continued)

\begin{tabular}{|c|c|c|c|c|c|}
\hline 18 & 2.78 & HERC2 & $\begin{array}{l}\text { Probable E3 ubiquitin- } \\
\text { protein ligase HERC2 }\end{array}$ & ubiquitin-protein ligase activity & $\begin{array}{l}\text { protein metabolic process; ectoderm } \\
\text { development; mesoderm development; } \\
\text { skeletal system development; nervous } \\
\text { system development }\end{array}$ \\
\hline 19 & 2.76 & PCSK6 & $\begin{array}{l}\text { Proprotein convertase } \\
\text { subtilisin/kexin type } 6\end{array}$ & peptidase activity & $\begin{array}{l}\text { cell surface receptor linked signal } \\
\text { transduction; cell-matrix adhesion; protein } \\
\text { metabolic process; signal transduction; } \\
\text { mesoderm development }\end{array}$ \\
\hline 20 & 2.76 & UCK2 & Uridine-cytidine kinase 2 & $\begin{array}{l}\text { kinase activity; transferase activity, } \\
\text { transferring glycosyl groups }\end{array}$ & $\begin{array}{l}\text { carbohydrate metabolic process; nucleobase, } \\
\text { nucleoside, nucleotide and nucleic acid } \\
\text { metabolic process }\end{array}$ \\
\hline 21 & 2.76 & WFDC5 & $\begin{array}{l}\text { WAP four-disulfide core } \\
\text { domain protein } 5\end{array}$ & protein binding;peptidase inhibitor activity & protein metabolic process \\
\hline 22 & 2.75 & RPS10 & $40 \mathrm{~S}$ ribosomal protein $\mathrm{S} 10$ & $\begin{array}{l}\text { structural constituent of ribosome; nucleic } \\
\text { acid binding }\end{array}$ & protein metabolic process \\
\hline 23 & 2.75 & SLC7A14 & $\begin{array}{l}\text { Probable cationic amino } \\
\text { acid transporter }\end{array}$ & $\begin{array}{l}\text { amino acid transmembrane transporter } \\
\text { activity; transmembrane transporter activity }\end{array}$ & $\begin{array}{l}\text { amino acid transport; cellular amino acid } \\
\text { and derivative metabolic process }\end{array}$ \\
\hline 24 & 2.75 & UBQLN2 & Ubiquilin-2;UBQLN2 & & protein metabolic process \\
\hline 25 & 2.70 & CLEC7A & $\begin{array}{l}\text { C-type lectin domain family } \\
7 \text { member A }\end{array}$ & receptor activity; receptor binding & $\begin{array}{l}\text { B cell mediated immunity; natural killer cell } \\
\text { activation; intracellular protein transport; } \\
\text { endocytosis; signal transduction; cell-cell } \\
\text { adhesion; signal transduction; cellular } \\
\text { defense response }\end{array}$ \\
\hline 26 & 2.70 & SH3BP1 & $\begin{array}{l}\text { SH3 domain-binding } \\
\text { protein } 1\end{array}$ & $\begin{array}{l}\text { protein binding; small GTPase regulator } \\
\text { activity }\end{array}$ & $\begin{array}{l}\text { cell surface receptor linked signal } \\
\text { transduction; signal transduction; cellular } \\
\text { component morphogenesis }\end{array}$ \\
\hline 27 & 2.68 & HMGB2 & $\begin{array}{l}\text { High mobility group } \\
\text { protein B2 }\end{array}$ & $\begin{array}{l}\text { DNA binding; chromatin binding; receptor } \\
\text { binding; transcription factor activity }\end{array}$ & $\begin{array}{l}\text { intracellular signaling cascade; nucleobase, } \\
\text { nucleoside, nucleotide and nucleic acid } \\
\text { metabolic process; signal transduction; } \\
\text { organelle organization; establishment or } \\
\text { maintenance of chromatin architecture }\end{array}$ \\
\hline 28 & 2.68 & TMSB10 & Thymosin beta-10 & & \\
\hline 29 & 2.67 & NEFM & $\begin{array}{l}\text { Neurofilament medium } \\
\text { polypeptide }\end{array}$ & structural constituent of cytoskeleton & $\begin{array}{l}\text { cellular component morphogenesis; } \\
\text { ectoderm development }\end{array}$ \\
\hline 30 & 2.67 & ZNF274 & Zinc finger protein 274 & DNA binding;transcription factor activity & $\begin{array}{l}\text { nucleobase, nucleoside, nucleotide and } \\
\text { nucleic acid metabolic process }\end{array}$ \\
\hline 31 & 2.66 & PCDH19 & Protocadherin-19 & $\begin{array}{l}\text { G-protein coupled receptor activity; calcium } \\
\text { ion binding }\end{array}$ & $\begin{array}{l}\text { cell surface receptor linked signal } \\
\text { transduction; cell-cell adhesion; cell motion, } \\
\text { signal transduction; cellular component } \\
\text { morphogenesis; ectoderm development; } \\
\text { mesoderm development; embryonic } \\
\text { development; nervous system development; } \\
\text { heart development; muscle organ } \\
\text { development }\end{array}$ \\
\hline 32 & 2.61 & KCMF1 & $\begin{array}{l}\text { E3 ubiquitin-protein ligase } \\
\text { KCMF1 }\end{array}$ & & \\
\hline 33 & 2.60 & PIP4K2B & $\begin{array}{l}\text { Phosphatidylinositol-5- } \\
\text { phosphate 4-kinase type-2 } \\
\text { beta }\end{array}$ & kinase activity & $\begin{array}{l}\text { cell surface receptor linked signal } \\
\text { transduction; lipid metabolic process; signal } \\
\text { transduction }\end{array}$ \\
\hline 34 & 2.57 & GNAT3 & $\begin{array}{l}\text { Guanine nucleotide- } \\
\text { binding protein } \mathrm{G}(\mathrm{t}) \\
\text { subunit alpha-3 }\end{array}$ & GTPase activity; protein binding & $\begin{array}{l}\text { cell surface receptor linked signal } \\
\text { transduction; signal transduction }\end{array}$ \\
\hline 35 & 2.56 & LPCAT1 & $\begin{array}{l}\text { 1- } \\
\text { acylglycerophosphocholine } \\
\text { O-acyltransferase } 1\end{array}$ & $\begin{array}{l}\text { acyltransferase activity; calcium ion binding; } \\
\text { calmodulin binding; calcium-dependent } \\
\text { phospholipid binding }\end{array}$ & metabolic process \\
\hline 36 & 2.56 & XPR1 & $\begin{array}{l}\text { Xenotropic and polytropic } \\
\text { retrovirus receptor } 1\end{array}$ & G-protein coupled receptor activity & $\begin{array}{l}\text { cell surface receptor linked signal } \\
\text { transduction; signal transduction; embryonic } \\
\text { development }\end{array}$ \\
\hline
\end{tabular}


Table 2 Up-regulated genes in cancer cells grown as a co-culture with CAFs (Continued)

\begin{tabular}{llll}
\hline 37 & 2.54 & LPHN2 & Latrophilin-2
\end{tabular}

immune system process; neurotransmitter secretion; intracellular protein transport; exocytosis; cell surface receptor linked signal transduction; synaptic transmission; cell adhesion; cell-cell signaling; mesoderm development; angiogenesis; heart development

\begin{tabular}{lllll}
\hline 38 & 2.54 & MPHOSPH6 & M-phase phosphoprotein 6 & \\
\hline 39 & 2.52 & NDUFB10 & $\begin{array}{l}\text { NADH dehydrogenase } \\
\text { [ubiquinone] } 1 \text { beta } \\
\text { subcomplex subunit 10 }\end{array}$ & oxidoreductase activity \\
& & &
\end{tabular}

\begin{tabular}{lllll}
\hline 40 & 2.51 & DSP & Desmoplakin & $\begin{array}{l}\text { structural constituent of cytoskeleton; } \\
\text { cytoskeletal protein binding }\end{array}$ \\
\hline 41 & 2.51 & EXOC3L2 & Exocyst complex &
\end{tabular}

cell cycle

oxidative phosphorylation; respiratory electron transport chain

\section{cell adhesion; cellular component} morphogenesis; ectoderm development

spermatogenesis; immune response; macrophage activation; intracellular protein transport; exocytosis; mesoderm development; angiogenesis; hemopoiesis; response to stimulus

\begin{tabular}{|c|c|c|c|}
\hline 42 & 2.50 & UBXN1 & $\begin{array}{l}\text { UBX domain-containing } \\
\text { protein } 1\end{array}$ \\
\hline 43 & 2.49 & MYOT & Myotilin; \\
\hline 44 & 2.49 & SHPRH & DNA helicase activity; nucleic acid binding \\
\hline
\end{tabular}

\begin{tabular}{|c|c|c|c|c|c|}
\hline 45 & 2.49 & SMYD1 & $\begin{array}{l}\text { SET and MYND domain- } \\
\text { containing protein } 1\end{array}$ & $\begin{array}{l}\text { DNA binding; transcription factor activity; } \\
\text { transcription cofactor activity }\end{array}$ & $\begin{array}{l}\text { nucleobase, nucleoside, nucleotide and } \\
\text { nucleic acid metabolic process }\end{array}$ \\
\hline 46 & 2.48 & KTN1 & Kinectin & structural constituent of cytoskeleton & $\begin{array}{l}\text { intracellular protein transport; cellular } \\
\text { component morphogenesis }\end{array}$ \\
\hline 47 & 2.48 & PJA2 & $\begin{array}{l}\text { E3 ubiquitin-protein ligase } \\
\text { Praja2 }\end{array}$ & DNA binding; transcription factor activity & \\
\hline 48 & 2.48 & SRPK1 & $\begin{array}{l}\text { Serine/threonine-protein } \\
\text { kinase SRPK1 }\end{array}$ & kinase activity & $\begin{array}{l}\text { immune system process; mitosis; cell surface } \\
\text { receptor linked signal transduction; } \\
\text { intracellular signaling cascade; carbohydrate } \\
\text { metabolic process; protein metabolic } \\
\text { process; cell motion; mitosis; signal } \\
\text { transduction; segment specification; } \\
\text { ectoderm development; mesoderm } \\
\text { development; embryonic development; } \\
\text { nervous system development; response to } \\
\text { stress }\end{array}$ \\
\hline
\end{tabular}

\begin{tabular}{|c|c|c|c|c|c|}
\hline 49 & 2.47 & ANKS3 & $\begin{array}{l}\text { Ankyrin repeat and SAM } \\
\text { domain-containing protein } \\
3\end{array}$ & & \\
\hline 50 & 2.47 & C20orf26 & $\begin{array}{l}\text { Uncharacterized protein } \\
\text { C20orf26 }\end{array}$ & & \\
\hline 51 & 2.47 & TREML2 & $\begin{array}{l}\text { Trem-like transcript } 2 \\
\text { protein }\end{array}$ & & \\
\hline 52 & 2.46 & TAB2 & $\begin{array}{l}\text { Mitogen-activated protein } \\
\text { kinase kinase kinase } 7 \text { - } \\
\text { interacting protein } 2\end{array}$ & DNA binding; transcription factor activity & $\begin{array}{l}\text { nucleobase, nucleoside, nucleotide and } \\
\text { nucleic acid metabolic process }\end{array}$ \\
\hline 53 & 2.45 & C19orf6 & Membralin & structural molecule activity & \\
\hline 54 & 2.45 & EPB41L2 & Band 4.1-like protein 2 & & \\
\hline 55 & 2.44 & CCDC71 & $\begin{array}{l}\text { Coiled-coil domain- } \\
\text { containing protein } 71\end{array}$ & & \\
\hline 56 & 2.44 & FGD1 & $\begin{array}{l}\text { FYVE, RhoGEF and } \mathrm{PH} \\
\text { domain-containing protein } \\
1\end{array}$ & $\begin{array}{l}\text { protein binding; small GTPase regulator } \\
\text { activity; guanyl-nucleotide exchange factor } \\
\text { activity }\end{array}$ & $\begin{array}{l}\text { mesoderm development; skeletal system } \\
\text { development }\end{array}$ \\
\hline
\end{tabular}




\section{Table 2 Up-regulated genes in cancer cells grown as a co-culture with CAFs (Continued)}

\begin{tabular}{llll}
\hline 572.44 & VCAM1 & $\begin{array}{l}\text { Vascular cell adhesion } \\
\text { protein } 1\end{array}$ & $\begin{array}{l}\text { hydrolase activity, acting on ester bonds; } \\
\text { phosphatase activity; receptor activity }\end{array}$
\end{tabular}

phosphatase activity; receptor activity

immune system process; muscle contraction; induction of apoptosis; cell cycle; cell surface receptor linked signal transduction; cell-cell signaling; cell-cell adhesion; protein metabolic process; cell motion; cell cycle; signal transduction; ectoderm development; mesoderm development; angiogenesis; nervous system development; muscle organ development

\begin{tabular}{llll}
\hline 58 & $2.42 \quad$ ANKRA2 & $\begin{array}{l}\text { Ankyrin repeat family A DNA binding; transcription factor activity } \\
\text { protein } 2\end{array}$
\end{tabular}

antigen processing and presentation of peptide or polysaccharide antigen via $\mathrm{MHC}$ class II; cellular defense response

\begin{tabular}{llll}
\hline 592.42 & KCNK17 & $\begin{array}{l}\text { Potassium channel } \\
\text { subfamily K member 17 }\end{array}$ & $\begin{array}{l}\text { cation transmembrane transporter activity; } \\
\text { voltage-gated potassium channel activity; } \\
\text { cation channel activity }\end{array}$ \\
\hline
\end{tabular}
neurological system process; cation transport cation channel activity

\begin{tabular}{lllll}
\hline 60 & 2.42 & TXNDC15 & $\begin{array}{l}\text { Thioredoxin domain- } \\
\text { containing protein 15 }\end{array}$ & \\
\hline 61 & 2.41 & TBPL2 & $\begin{array}{l}\text { TATA box-binding protein- } \\
\text { like protein 2 }\end{array}$ & DNA binding; transcription factor activity \\
\hline 62 & 2.40 & ALDH3A2 & $\begin{array}{l}\text { Fatty aldehyde } \\
\text { dehydrogenase }\end{array}$ & oxidoreductase activity
\end{tabular}

nucleobase, nucleoside, nucleotide and nucleic acid metabolic process

carbohydrate metabolic process; nucleobase, nucleoside, nucleotide and nucleic acid metabolic process; cellular amino acid and derivative metabolic process

\begin{tabular}{|c|c|c|c|c|c|}
\hline 63 & 2.40 & LAMP3 & $\begin{array}{l}\text { Lysosome-associated } \\
\text { membrane glycoprotein } 3\end{array}$ & & $\begin{array}{l}\text { lysosomal transport; intracellular protein } \\
\text { transport; protein metabolic process }\end{array}$ \\
\hline 64 & 2.40 & PNLIP & $\begin{array}{l}\text { Pancreatic triacylglycerol } \\
\text { lipase }\end{array}$ & hydrolase activity, acting on ester bonds & lipid metabolic process \\
\hline
\end{tabular}

$65 \quad 2.37 \quad$ C17orf28 UPF0663 transmembrane

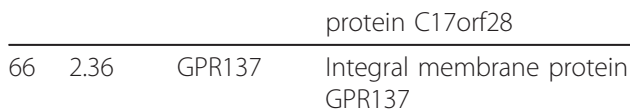

\begin{tabular}{lllll}
\hline 67 & 2.35 & WARS & $\begin{array}{l}\text { Tryptophanyl-tRNA } \\
\text { synthetase, cytoplasmic }\end{array}$ & aminoacyl-tRNA ligase activity \\
\hline
\end{tabular}

\begin{tabular}{llll}
\hline 68 & 2.34 & C11orf35 & $\begin{array}{l}\text { Uncharacterized protein } \\
\text { C11orf35 }\end{array}$ \\
\hline 69 & 234 & SCML2 & Sex comb on midleg-like $\quad$ DNA binding chromatin binding
\end{tabular}
$\begin{array}{llll}692.34 \quad \text { SCML2 } & \text { Sex comb on midleg-like } & \text { DNA binding; chromatin binding; } \\ & \text { protein } 2 & \text { transcription factor activity }\end{array}$

cell cycle; nucleobase, nucleoside, nucleotide and nucleic acid metabolic process; cell cycle; organelle organization; establishment or maintenance of chromatin architecture; ectoderm development; mesoderm development; nervous system development

\begin{tabular}{llll}
\hline 70 & $2.33 \quad$ GNL1 & Guanine nucleotide- & GTPase activity; nucleic acid binding;
\end{tabular}
intracellular protein transport; cell surface receptor linked signal transduction; intracellular signaling cascade; nucleobase, nucleoside, nucleotide and nucleic acid metabolic process; signal transduction

\begin{tabular}{|c|c|c|c|c|c|}
\hline 71 & 2.33 & MORN1 & $\begin{array}{l}\text { MORN repeat-containing } \\
\text { protein } 1\end{array}$ & kinase activity & $\begin{array}{l}\text { cell surface receptor linked signal } \\
\text { transduction; signal transduction }\end{array}$ \\
\hline 72 & 2.33 & TMEM149 & $\begin{array}{l}\text { Transmembrane protein } \\
149\end{array}$ & & \\
\hline 73 & 2.32 & AK4 & $\begin{array}{l}\text { Adenylate kinase } \\
\text { isoenzyme 4, mitochondrial }\end{array}$ & kinase activity & $\begin{array}{l}\text { nucleobase, nucleoside, nucleotide and } \\
\text { nucleic acid metabolic process }\end{array}$ \\
\hline 74 & 2.32 & TOMM34 & $\begin{array}{l}\text { Mitochondrial import } \\
\text { receptor subunit TOM34 }\end{array}$ & & $\begin{array}{l}\text { immune system process; protein metabolic } \\
\text { process; response to stress }\end{array}$ \\
\hline 75 & 2.32 & ZNHIT6 & $\begin{array}{l}\text { Zinc finger HIT domain- } \\
\text { containing protein } 6\end{array}$ & & \\
\hline 76 & 2.31 & BTG1 & Protein BTG1 & & $\begin{array}{l}\text { cell cycle; intracellular signaling cascade; } \\
\text { signal transduction }\end{array}$ \\
\hline 77 & 2.30 & GRAMD1A & $\begin{array}{l}\text { GRAM domain-containing } \\
\text { protein } 1 \mathrm{~A}\end{array}$ & & \\
\hline
\end{tabular}




\section{Table 2 Up-regulated genes in cancer cells grown as a co-culture with CAFs (Continued)}

\begin{tabular}{|c|c|c|c|c|c|}
\hline 78 & 2.30 & GRIK5 & $\begin{array}{l}\text { Glutamate receptor, } \\
\text { ionotropic kainate } 5\end{array}$ & $\begin{array}{l}\text { glutamate receptor activity; ligand-gated ion } \\
\text { channel activity }\end{array}$ & $\begin{array}{l}\text { neurological system process; cation } \\
\text { transport; cell surface receptor linked signal } \\
\text { transduction; synaptic transmission; signal } \\
\text { transduction; cell-cell signaling }\end{array}$ \\
\hline 79 & 2.30 & TDRKH & $\begin{array}{l}\text { Tudor and KH domain- } \\
\text { containing protein }\end{array}$ & $\begin{array}{l}\text { hydrolase activity, acting on ester bonds; } \\
\text { nucleic acid binding }\end{array}$ & $\begin{array}{l}\text { nucleobase, nucleoside, nucleotide and } \\
\text { nucleic acid metabolic process }\end{array}$ \\
\hline 80 & 2.30 & TGIF1 & Homeobox protein TGIF1 & $\begin{array}{l}\text { DNA-directed RNA polymerase activity; DNA } \\
\text { binding; transcription factor activity }\end{array}$ & $\begin{array}{l}\text { nucleobase, nucleoside, nucleotide and } \\
\text { nucleic acid metabolic process; ectoderm } \\
\text { development; nervous system development }\end{array}$ \\
\hline 81 & 2.29 & FAM81B & Protein FAM81B & & \\
\hline 82 & 2.29 & MRPL9 & $\begin{array}{l}395 \text { ribosomal protein } L 9 \text {, } \\
\text { mitochondrial }\end{array}$ & $\begin{array}{l}\text { structural constituent of ribosome; nucleic } \\
\text { acid binding }\end{array}$ & protein metabolic process \\
\hline 83 & 2.28 & ANKRD46 & $\begin{array}{l}\text { Ankyrin repeat domain- } \\
\text { containing protein } 46\end{array}$ & & \\
\hline 84 & 2.27 & INSM1 & $\begin{array}{l}\text { Insulinoma-associated } \\
\text { protein } 1\end{array}$ & & $\begin{array}{l}\text { nucleobase, nucleoside, nucleotide and } \\
\text { nucleic acid metabolic process }\end{array}$ \\
\hline 85 & 2.27 & PBX1 & $\begin{array}{l}\text { Pre-B-cell leukemia } \\
\text { transcription factor } 1\end{array}$ & $\begin{array}{l}\text { DNA-directed RNA polymerase activity; DNA } \\
\text { binding; transcription factor activity }\end{array}$ & $\begin{array}{l}\text { nucleobase, nucleoside, nucleotide and } \\
\text { nucleic acid metabolic process; ectoderm } \\
\text { development; mesoderm development; } \\
\text { nervous system development; hemopoiesis }\end{array}$ \\
\hline
\end{tabular}

\begin{tabular}{llllll}
\hline 86 & 2.27 & TPRG1 & $\begin{array}{l}\text { Tumor protein p63- } \\
\text { regulated gene 1 protein }\end{array}$ & \\
\hline 87 & 2.26 & SEPT4 & Septin-4 & $\begin{array}{l}\text { GTPase activity;structural constituent of } \\
\text { cytoskeleton; protein binding }\end{array}$ & mitosis; cytokinesis \\
\hline
\end{tabular}

\begin{tabular}{|c|c|c|c|c|}
\hline 88 & 2.25 & FAM159B & $\begin{array}{l}\text { UPF0514 membrane } \\
\text { protein FAM159B }\end{array}$ & \\
\hline 89 & 2.24 & AKAP8 & A-kinase anchor protein 8 & \\
\hline 90 & 2.24 & FAM83A & Protein FAM83A & \\
\hline 91 & 2.24 & MAG & $\begin{array}{l}\text { Myelin-associated } \\
\text { glycoprotein }\end{array}$ & $\begin{array}{l}\text { receptor activity; structural constituent of } \\
\text { myelin sheath; receptor binding }\end{array}$ \\
\hline
\end{tabular}

mitosis; chromosome segregation

\begin{tabular}{llllll}
\hline 92 & 2.24 & SCN9A & $\begin{array}{l}\text { Sodium channel protein } \\
\text { type } 9 \text { subunit alpha }\end{array}$ & $\begin{array}{l}\text { cation transmembrane transporter activity; } \\
\text { voltage-gated sodium channel activity; } \\
\text { cation channel activity }\end{array}$ & $\begin{array}{l}\text { neuronal action potential propagation; } \\
\text { cation transport }\end{array}$ \\
\hline 93 & 2.23 & ASTN1 & Astrotactin-1 & & \\
\hline 94 & 2.23 & RAB7L1 & $\begin{array}{l}\text { Ras-related protein Rab-7 } \\
\text { L1 }\end{array}$ & GTPase activity; protein binding & $\begin{array}{l}\text { neurotransmitter secretion; intracellular } \\
\text { protein transport; exocytosis; endocytosis; }\end{array}$
\end{tabular}

\begin{tabular}{lllll}
\hline 92 & 2.24 & SCN9A & $\begin{array}{l}\text { Sodium channel protein } \\
\text { type 9 subunit alpha }\end{array}$ & $\begin{array}{l}\text { cation transmembrane transporter } \\
\text { voltage-gated sodium channel activt } \\
\text { cation channel activity }\end{array}$ \\
\hline 93 & 2.23 & ASTN1 & Astrotactin-1 & \\
\hline 94 & 2.23 & RAB7L1 & $\begin{array}{l}\text { Ras-related protein Rab-7 } \\
\text { L1 }\end{array}$ & GTPase activity; protein binding
\end{tabular}

B cell mediated immunity; cell surface receptor linked signal transduction; cell-cell adhesion; signal transduction; ectoderm development; nervous system development; response to stimulus

\begin{tabular}{llllll}
\hline 95 & 2.22 & RASA3 & $\begin{array}{l}\text { Ras GTPase-activating } \\
\text { protein 3 }\end{array}$ & $\begin{array}{l}\text { protein binding; small GTPase regulator } \\
\text { activity }\end{array}$ & signal transduction \\
\hline 96 & 2.22 & TMEM59L & $\begin{array}{l}\text { Transmembrane protein 59- } \\
\text { like }\end{array}$ & & \\
\hline 97 & 2.21 & CACNB3 & $\begin{array}{l}\text { Voltage-dependent L-type } \\
\text { calcium channel subunit } \\
\text { beta-3 }\end{array}$ & $\begin{array}{l}\text { cation transmembrane transporter activity; } \\
\text { voltage-gated calcium channel activity; } \\
\text { cation channel activity }\end{array}$ & $\begin{array}{l}\text { muscle contraction; neurotransmitter } \\
\text { secretion; synaptic transmission; cell-cell } \\
\text { signaling }\end{array}$ \\
\hline 98 & 2.21 & PLCD3 & $\begin{array}{l}\text { 1-phosphatidylinositol-4,5- } \\
\text { bisphosphate } \\
\text { phosphodiesterase delta-3 }\end{array}$ & $\begin{array}{l}\text { hydrolase activity, acting on ester bonds; } \\
\text { calcium ion binding }\end{array}$ & $\begin{array}{l}\text { cell surface receptor linked signal } \\
\text { transduction; lipid metabolic process; signal } \\
\text { transduction }\end{array}$ \\
\hline 99 & 2.21 & PLCH1 & $\begin{array}{l}\text { 1-phosphatidylinositol-4,5- } \\
\text { bisphosphate } \\
\text { phosphodiesterase eta-1 }\end{array}$ & $\begin{array}{l}\text { hydrolase activity, acting on ester bonds; } \\
\text { calcium ion binding; receptor binding; small } \\
\text { GTPase regulator activity; guanyl-nucleotide } \\
\text { exchange factor activity }\end{array}$ & $\begin{array}{l}\text { cell surface receptor linked signal } \\
\text { transduction; intracellular signaling cascade; } \\
\text { lipid metabolic process; signal transduction }\end{array}$ \\
\hline 100 & 2.21 & TULP1 & Tubby-related protein 1 & & $\begin{array}{l}\text { visual perception; sensory perception; } \\
\text { ectoderm development; nervous system } \\
\text { development }\end{array}$ \\
\hline
\end{tabular}


Table 2 Up-regulated genes in cancer cells grown as a co-culture with CAFs (Continued)

\begin{tabular}{|c|c|c|c|c|c|}
\hline 101 & 2.20 & EFCAB6 & $\begin{array}{l}\text { EF-hand calcium-binding } \\
\text { domain-containing protein } \\
\text { 6;EFCAB6 }\end{array}$ & $\begin{array}{l}\text { calcium ion binding; receptor binding; } \\
\text { calmodulin binding; enzyme regulator } \\
\text { activity }\end{array}$ & $\begin{array}{l}\text { cation transport; cell cycle;signal } \\
\text { transduction; cell cycle; signal transduction }\end{array}$ \\
\hline 102 & 2.19 & PTPN6 & $\begin{array}{l}\text { Tyrosine-protein } \\
\text { phosphatase non-receptor } \\
\text { type } 6\end{array}$ & $\begin{array}{l}\text { hydrolase activity, acting on ester bonds; } \\
\text { phosphatase activity; receptor activity }\end{array}$ & $\begin{array}{l}\text { immune system process; intracellular protein } \\
\text { transport; mitosis; cell surface receptor linked } \\
\text { signal transduction; intracellular signaling } \\
\text { cascade; cell-matrix adhesion; cell-cell } \\
\text { adhesion; protein metabolic process; } \\
\text { cytokinesis; cell motion; signal transduction; } \\
\text { nervous system development; cellular } \\
\text { glucose homeostasis }\end{array}$ \\
\hline 103 & 2.18 & GPR155 & $\begin{array}{l}\text { Integral membrane protein } \\
\text { GPR155 }\end{array}$ & receptor activity & \\
\hline 104 & 2.18 & PSPN & Persephin & receptor binding & $\begin{array}{l}\text { neurological system process; cell surface } \\
\text { receptor linked signal transduction; cell-cell } \\
\text { signaling; signal transduction; ectoderm } \\
\text { development; nervous system development }\end{array}$ \\
\hline 105 & 2.18 & STAM2 & $\begin{array}{l}\text { Signal transducing adapter } \\
\text { molecule } 2\end{array}$ & $\begin{array}{l}\text { transmembrane transporter activity; protein } \\
\text { binding; kinase activator activity; kinase } \\
\text { regulator activity }\end{array}$ & $\begin{array}{l}\text { lysosomal transport; intracellular protein } \\
\text { transport; endocytosis; intracellular signaling } \\
\text { cascade; signal transduction }\end{array}$ \\
\hline 106 & 2.17 & AGXT2L2 & $\begin{array}{l}\text { Alanine-glyoxylate } \\
\text { aminotransferase 2-like } 2\end{array}$ & transaminase activity & $\begin{array}{l}\text { visual perception; sensory perception; } \\
\text { vitamin biosynthetic process; cellular amino } \\
\text { acid and derivative metabolic process }\end{array}$ \\
\hline
\end{tabular}

The list of up-regulated genes in cancer cells grown as a co-culture with carcinoma-associated fibroblasts (CAFs). Gene ID, name, molecular function and biological process are listed according to the Panther Database classification www.pantherdb.org. The analyzed genes were significantly up-regulated at the level of $p<0.05$, fold change $>2.0$.

The results of the study hereby revealed increased expression of 13 genes involved in cell adhesion (Table 2) among cancer cells co-cultured with the CAFs. As much as 10 of them are involved in developmental processes as well. These genes seem to be particularly significant because the cell adhesion is responsible for tumour progression and metastasis, detachment from the primary tumour and spreading to the circulatory system. Moreover, the up-regulated genes responsible for adhesion are by rule involved in angiogenesis and lymphangiogenesis. For example, the vascular cell adhesion molecule-1 (VCAM-1) up-regulated in cancer cells grown as a co-culture with CAFs may be involved in tumor progression and metastasis particularly via lymphangiogenesis promotion $[37,38]$. It also has previously been demonstrated that the VCAM-1 plays a crucial role in the endothelial-carcinoma cell adhesion [38].

The study also revealed an up-regulation of desmoplakin (DSP), which is a key component of cellular adhesion junctions known as desmosomes. These junctions are found at contact sites between endothelial cells that form capillaries, thus DSP play a role in de novo capillary formation and branching during tumourigenesis, embryonic development and cardiovascular development [39]. Moreover, desmoplakin isoform 2 was only detected in tumours associated with a poor clinical outcome. It may suggest its potentially specific function in the regulation of cancer cells proliferation, differentiation, invasion and metastasis $[40,41]$.
Moreover, desmosomes may also be important in the epithelium-mesenchymal transition (EMT). The epithelium-mesenchymal transition is an indispensable mechanism for morphogenesis during embryonic development, and is implicated in conversion of early-stage tumours into invasive cancers. During EMT, epithelial cells undergo changes in morphology and acquire the migratory and invasive characteristics of mesenchymal cells [30]. EMT is also promoted by the FOXQ1, another up-regulated gene in cancer cells grown under co-culture conditions with the CAFs [42]. It also increases expression of several junction proteins promoting cancer cells to gain the stem-cell-like properties and ensuring resistance to apoptosis [42-44]. Moreover, the down regulation of keratin 20 (Table 3 ) in cancer cells following the co-culture with the CAFs may indicate the EMT induction [45,46].

Interestingly, another up-regulated gene in cancer cells grown with the CAFs, which contributes to cancer invasion is myelin-associated glycoprotein (MAG) that binds to the oncogenic glycoprotein MUC1 [47]. Swanson et al. [47] described an interaction between the MUC1 and the MAG in cancers that invade perineurally, including prostate, salivary, and breast carcinomas. Furthermore, breast cancers may metastasize to the brain where the MAG is abundantly expressed. Interactions between the MUC1 and the MAG have not fully been defined yet. We confirmed the MUC1 expression in all of the examined cell lines (Figure 6). Thus, based on our own 
Table 3 Down-regulated genes in cancer cells grown as a co-culture with CAFs

\begin{tabular}{|c|c|c|c|c|c|}
\hline No & $\begin{array}{l}\text { Fold } \\
\text { change }\end{array}$ & Gene ID & Gene name & Molecular function & Biological process \\
\hline 1 & 2.17 & EPS8L1 & $\begin{array}{l}\text { Epidermal growth factor receptor } \\
\text { kinase substrate 8-like protein } 1\end{array}$ & & $\begin{array}{l}\text { intracellular signaling cascade; cell } \\
\text { motion; signal transduction }\end{array}$ \\
\hline 2 & 2.17 & OR4X1 & Olfactory receptor $4 \mathrm{X} 1$ & & \\
\hline 3 & 2.18 & C2orf61 & Uncharacterized protein C2orf61 & & \\
\hline 4 & 2.18 & DSN1 & $\begin{array}{l}\text { Kinetochore-associated protein } \\
\text { DSN1 homolog }\end{array}$ & & \\
\hline 5 & 2.18 & PFAS & $\begin{array}{l}\text { Phosphoribosylformylglycinamidine } \\
\text { synthase }\end{array}$ & ligase activity & $\begin{array}{l}\text { nucleobase, nucleoside, nucleotide and } \\
\text { nucleic acid metabolic process }\end{array}$ \\
\hline 6 & 2.18 & SLC5A2 & Sodium/glucose cotransporter 2 & $\begin{array}{l}\text { carbohydrate transmembrane } \\
\text { transporter activity; cation } \\
\text { transmembrane transporter activity }\end{array}$ & $\begin{array}{l}\text { cation transport; extracellular transport; } \\
\text { amino acid transport; carbohydrate } \\
\text { metabolic process; cellular amino acid } \\
\text { and derivative metabolic process }\end{array}$ \\
\hline 7 & 2.18 & TMEM138 & Transmembrane protein 138 & & \\
\hline 8 & 2.19 & FOLR1 & Folate receptor alpha & $\begin{array}{l}\text { receptor activity;transmembrane } \\
\text { transporter activity }\end{array}$ & vitamin transport \\
\hline 9 & 2.19 & MFN2 & Mitofusin-2 & $\begin{array}{l}\text { hydrolase activity, acting on ester } \\
\text { bonds; phosphatase activity }\end{array}$ & $\begin{array}{l}\text { intracellular protein transport; organelle } \\
\text { organization; mitochondrion } \\
\text { organization }\end{array}$ \\
\hline
\end{tabular}

\begin{tabular}{lllll}
\hline 10 & 2.19 & NDRG3 & Protein NDRG3 & \\
\hline 11 & 2.19 & UNC13D & Protein unc-13 homolog D & intracellular protein transport; exocytosis \\
\hline 12 & 2.20 & GOLPH3 & Golgi phosphoprotein 3
\end{tabular}

$132.20 \quad$ SLC22A13 Solute carrier family 22 member 13 ATPase activity, coupled to cation transport; anion transport; transmembrane movement of extracellular transport; carbohydrate substances; ligase activity; carbohydrate transport; carbohydrate metabolic transmembrane transporter activity; process cation transmembrane transporter activity

\begin{tabular}{lllll}
\hline 14 & 2.20 & USP54 & $\begin{array}{l}\text { Inactive ubiquitin carboxyl-terminal } \\
\text { hydrolase 54 }\end{array}$ & ubiquitin-protein ligase activity \\
\hline 15 & 2.22 & NMI & N-myc-interactor & $\begin{array}{l}\text { DNA binding; transcription factor } \\
\text { activity; transcription cofactor activity }\end{array}$
\end{tabular}

protein metabolic process response to interferon-gamma; intracellular signaling cascade; signal transduction; cellular defense response

\begin{tabular}{llll}
\hline 16 & 2.22 & PDCD1 & Programmed cell death protein 1 \\
\hline 17 & 2.22 & SNRPN & $\begin{array}{l}\text { Small nuclear ribonucleoprotein- } \\
\text { associated protein N }\end{array}$
\end{tabular}

RNA splicing factor activity, transesterification mechanism; RNA binding

\begin{tabular}{llll}
\hline 18 & 2.23 & SPSB1 & $\begin{array}{l}\text { SPRY domain-containing SOCS box } \\
\text { protein } 1\end{array}$
\end{tabular}

192.24 ADAMTS15 A disintegrin and metalloproteinase peptidase activity; protein binding; with thrombospondin motifs 15 nucleobase, nucleoside, nucleotide and nucleic acid metabolic process

\section{peptidase inhibitor activity}

fertilization; signal transduction; cellmatrix adhesion; cell-cell adhesion; protein metabolic process; signal transduction; ectoderm development; mesoderm development; skeletal system development; angiogenesis; nervous system development; muscle organ development protein metabolic process

translation factor activity, nucleic acid binding; translation release factor activity mitochondrial transmembrane transporter activity intracellular protein transport

\begin{tabular}{lllll}
\hline 21 & 2.24 & TOMM7 & $\begin{array}{l}\text { Mitochondrial import receptor } \\
\text { subunit TOM7 homolog }\end{array}$ & transmembrane transporter activity \\
\hline 22 & 2.25 & ATG7 & Autophagy-related protein 7 & ligase activity
\end{tabular}
intracellular signaling cascade; coenzyme metabolic process; protein metabolic process; signal transduction 
Table 3 Down-regulated genes in cancer cells grown as a co-culture with CAFs (Continued)

\begin{tabular}{lllll}
\hline 24 & 2.25 & USF2 & Upstream stimulatory factor 2 & DNA binding; transcription factor activity \\
\hline 25 & 2.26 & POGK & $\begin{array}{l}\text { Pogo transposable element with } \\
\text { KRAB domain }\end{array}$ & DNA binding \\
\hline 26 & 2.26 & ZNF804B & Zinc finger protein 804B & Programmed cell death 1 ligand 1 \\
\hline 27 & 2.27 & CD274 & $\begin{array}{l}\text { ubiquitin-protein ligase activity; receptor } \\
\text { activity; DNA binding; receptor binding; } \\
\text { transcription factor activity; transcription } \\
\text { cofactor activity }\end{array}$
\end{tabular}

ucleobase, nucleoside, nucleotide and nucleic acid metabolic process; lipid metabolic process

nucleobase, nucleoside, nucleotide and nucleic acid metabolic process; ectoderm development; nervous system development

immune system process;

neurotransmitter secretion; intracellular protein transport; exocytosis; signal transduction; synaptic transmission; nucleobase, nucleoside, nucleotide and nucleic acid metabolic process; protein metabolic process; cell-cell signaling; organelle organization; establishment or maintenance of chromatin architecture; mesoderm development; mammary gland development; response to stress; cellular defense response

\begin{tabular}{lllll}
\hline 28 & 2.27 & FAM132B & Protein FAM132B \\
\hline 29 & 2.27 & STK32C & $\begin{array}{l}\text { Serine/threonine-protein kinase 32 } \\
\text { C kinase activity }\end{array}$
\end{tabular}

cell cycle; intracellular signaling cascade; protein metabolic process; cell cycle; signal transduction

\begin{tabular}{lllll}
\hline 30 & 2.28 & CADM4 & Cell adhesion molecule 4 & receptor activity \\
\hline 31 & 2.28 & GLIPR2 & $\begin{array}{l}\text { Golgi-associated plant } \\
\text { pathogenesis-related protein 1 }\end{array}$ & immune system process \\
\hline 32 & 2.28 & GPR160 & $\begin{array}{l}\text { Probable G-protein coupled } \\
\text { receptor } 160\end{array}$ & \\
\hline 33 & 2.29 & GALNT2 & $\begin{array}{l}\text { Polypeptide } \mathrm{N} \text { - } \\
\text { acetylgalactosaminyltransferase 2 }\end{array}$ & $\begin{array}{l}\text { transferase activity, transferring glycosyl } \\
\text { groups }\end{array}$
\end{tabular}
soluble form

$342.29 \quad$ KRT20 Keratin, type I cytoskeletal $20 \quad$ structural constituent of cytoskeleton

cellular component morphogenesis; cellular component morphogenesis; ectoderm development; cellular component morphogenesis

\begin{tabular}{llll}
\hline 2529 & PTPN6 & $\begin{array}{l}\text { Tyrosine-protein phosphatase non- } \\
\text { receptor type } 6\end{array}$ & $\begin{array}{l}\text { hydrolase activity, acting on ester } \\
\text { bonds; phosphatase activity; receptor } \\
\end{array}$ \\
& activity
\end{tabular}
immune system process; intracellula protein transport; mitosis; cell surface receptor linked signal transduction; intracellular signaling cascade; cell-matrix adhesion; cell-cell adhesion; protein metabolic process; cytokinesis; cell motion; mitosis; signal transduction; nervous system development; cellular glucose homeostasis

\begin{tabular}{|c|c|c|c|c|c|}
\hline 36 & 2.29 & $\mathrm{SOHLH} 1$ & $\begin{array}{l}\text { Spermatogenesis- and oogenesis- } \\
\text { specific basic helix-loop-helix- } \\
\text { containing protein } 1\end{array}$ & & \\
\hline 37 & 2.31 & CENPM & Centromere protein $\mathrm{M}$ & & \\
\hline 38 & 2.31 & HPCAL1 & Hippocalcin-like protein 1 & $\begin{array}{l}\text { calcium ion binding; calmodulin } \\
\text { binding; small GTPase regulator activity }\end{array}$ & $\begin{array}{l}\text { visual perception; sensory perception; } \\
\text { cell surface receptor linked signal } \\
\text { transduction; signal transduction }\end{array}$ \\
\hline 40 & 2.32 & HOXA1 & Homeobox protein Hox-A1 & DNA binding; transcription factor activity & $\begin{array}{l}\text { female gamete generation; nucleobase, } \\
\text { nucleoside, nucleotide and nucleic acid } \\
\text { metabolic process; segment } \\
\text { specification; ectoderm development; } \\
\text { gut mesoderm development; embryonic } \\
\text { development; skeletal system } \\
\text { development; angiogenesis; nervous } \\
\text { system development; muscle organ } \\
\text { development }\end{array}$ \\
\hline
\end{tabular}


Table 3 Down-regulated genes in cancer cells grown as a co-culture with CAFs (Continued)

\begin{tabular}{|c|c|c|c|c|c|}
\hline 41 & 2.32 & $\mathrm{SMO}$ & Smoothened homolog & $\begin{array}{l}\text { G-protein coupled receptor activity; } \\
\text { receptor binding }\end{array}$ & $\begin{array}{l}\text { cell surface receptor linked signal } \\
\text { transduction; cell-cell signaling }\end{array}$ \\
\hline 42 & 2.33 & LAMP2 & $\begin{array}{l}\text { Lysosome-associated membrane } \\
\text { glycoprotein } 2\end{array}$ & & $\begin{array}{l}\text { lysosomal transport; intracellular protein } \\
\text { transport; protein metabolic process }\end{array}$ \\
\hline 43 & 2.33 & RNF121 & RING finger protein 121 & ubiquitin-protein ligase activity & protein metabolic process \\
\hline 44 & 2.34 & PLA2G2E & $\begin{array}{l}\text { Group IIE secretory phospholipase } \\
\text { A2 }\end{array}$ & hydrolase activity, acting on ester bonds & $\begin{array}{l}\text { signal transduction; lipid metabolic } \\
\text { process; signal transduction }\end{array}$ \\
\hline 45 & 2.34 & POU6F2 & $\begin{array}{l}\text { POU domain, class 6, transcription } \\
\text { factor } 2\end{array}$ & DNA binding; transcription factor activity & $\begin{array}{l}\text { nucleobase, nucleoside, nucleotide and } \\
\text { nucleic acid metabolic process }\end{array}$ \\
\hline 46 & 2.34 & PPP2R4 & $\begin{array}{l}\text { Serine/threonine-protein } \\
\text { phosphatase } 2 \mathrm{~A} \text { regulatory subunit } \\
\mathrm{B}^{\prime}\end{array}$ & $\begin{array}{l}\text { protein binding;phosphatase activator } \\
\text { activity; phosphatase regulator activity }\end{array}$ & protein metabolic process \\
\hline 47 & 2.34 & STX5 & Syntaxin-5 & SNAP receptor activity & $\begin{array}{l}\text { neurotransmitter secretion; intracellular } \\
\text { protein transport; exocytosis; } \\
\text { endocytosis; synaptic transmission; cell- } \\
\text { cell signaling }\end{array}$ \\
\hline 48 & 2.35 & DMC1 & $\begin{array}{l}\text { Meiotic recombination protein } \\
\text { DMC1/LIM15 homolog }\end{array}$ & hydrolase activity; DNA binding & $\begin{array}{l}\text { immune system process; meiosis; } \\
\text { nucleobase, nucleoside, nucleotide and } \\
\text { nucleic acid metabolic process; meiosis; } \\
\text { response to stress }\end{array}$ \\
\hline 49 & 2.35 & ERRFI1 & ERBB receptor feedback inhibitor 1 & & signal transduction;signal transduction \\
\hline 50 & 2.36 & TSPYL4 & $\begin{array}{l}\text { Testis-specific Y-encoded-like } \\
\text { protein } 4\end{array}$ & $\begin{array}{l}\text { protein binding; phosphatase inhibitor } \\
\text { activity; phosphatase regulator activity }\end{array}$ & $\begin{array}{l}\text { apoptosis; cell cycle; nucleobase, } \\
\text { nucleoside, nucleotide and nucleic acid } \\
\text { metabolic process; protein metabolic } \\
\text { process; cell cycle; organelle } \\
\text { organization; establishment or } \\
\text { maintenance of chromatin architecture }\end{array}$ \\
\hline 51 & 2.37 & USF1 & Upstream stimulatory factor 1 & DNA binding; transcription factor activity & $\begin{array}{l}\text { nucleobase, nucleoside, nucleotide and } \\
\text { nucleic acid metabolic process; lipid } \\
\text { metabolic process }\end{array}$ \\
\hline 52 & 2.40 & ARFGAP3 & $\begin{array}{l}\text { ADP-ribosylation factor GTPase- } \\
\text { activating protein } 3\end{array}$ & $\begin{array}{l}\text { nucleic acid binding; protein binding; } \\
\text { small GTPase regulator activity }\end{array}$ & $\begin{array}{l}\text { cell surface receptor linked signal } \\
\text { transduction; cell adhesion }\end{array}$ \\
\hline 53 & 2.40 & CNBP & $\begin{array}{l}\text { Cellular nucleic acid-binding } \\
\text { protein }\end{array}$ & nucleic acid binding & $\begin{array}{l}\text { nucleobase, nucleoside, nucleotide and } \\
\text { nucleic acid metabolic process; lipid } \\
\text { metabolic process }\end{array}$ \\
\hline 54 & 2.40 & NKD1 & Protein naked cuticle homolog 1 & & \\
\hline 55 & 2.41 & MRPL51 & $\begin{array}{l}395 \text { ribosomal protein L51, } \\
\text { mitochondrial; }\end{array}$ & $\begin{array}{l}\text { structural constituent of ribosome; } \\
\text { nucleic acid binding }\end{array}$ & protein metabolic process \\
\hline 56 & 2.41 & OPRK1 & Kappa-type opioid receptor & G-protein coupled receptor activity & $\begin{array}{l}\text { sensory perception; cell surface receptor } \\
\text { linked signal transduction; synaptic } \\
\text { transmission; cell motion; signal } \\
\text { transduction; cell-cell signaling }\end{array}$ \\
\hline 57 & 2.41 & PTX3 & Pentraxin-related protein PTX3 & & $\begin{array}{l}\text { immune response; response to stress; } \\
\text { defense response to bacterium }\end{array}$ \\
\hline 58 & 2.42 & GPRC5B & $\begin{array}{l}\text { G-protein coupled receptor family } \\
\text { C group } 5 \text { member B }\end{array}$ & G-protein coupled receptor activity & $\begin{array}{l}\text { cell surface receptor linked signal } \\
\text { transduction; signal transduction }\end{array}$ \\
\hline 59 & 2.42 & NGLY1 & $\begin{array}{l}\text { Peptide-N(4)-(N-acetyl-beta- } \\
\text { glucosaminyl)asparagine amidase }\end{array}$ & hydrolase activity & protein metabolic process \\
\hline 60 & 2.43 & CAPN12 & Calpain-12 & $\begin{array}{l}\text { peptidase activity; calcium ion binding; } \\
\text { calmodulin binding; calcium-dependent } \\
\text { phospholipid binding }\end{array}$ & $\begin{array}{l}\text { induction of apoptosis; intracellular } \\
\text { signaling cascade; protein metabolic } \\
\text { process; signal transduction }\end{array}$ \\
\hline 61 & 2.43 & POLD1 & $\begin{array}{l}\text { DNA polymerase delta catalytic } \\
\text { subunit }\end{array}$ & $\begin{array}{l}\text { DNA-directed DNA polymerase activity; } \\
\text { hydrolase activity, acting on ester } \\
\text { bonds; nucleic acid binding }\end{array}$ & $\begin{array}{l}\text { cell cycle; nucleobase, nucleoside, } \\
\text { nucleotide and nucleic acid metabolic } \\
\text { process; cell cycle }\end{array}$ \\
\hline 62 & 2.44 & TBC1D8 & TBC1 domain family member 8 & $\begin{array}{l}\text { hydrolase activity; protein binding; small } \\
\text { GTPase regulator activity }\end{array}$ & $\begin{array}{l}\text { intracellular protein transport; exocytosis; } \\
\text { cellular component morphogenesis }\end{array}$ \\
\hline 63 & 2.45 & DHRS11 & $\begin{array}{l}\text { Dehydrogenase/reductase SDR } \\
\text { family member } 11\end{array}$ & oxidoreductase activity & $\begin{array}{l}\text { visual perception; sensory perception; } \\
\text { lipid metabolic process }\end{array}$ \\
\hline
\end{tabular}


Table 3 Down-regulated genes in cancer cells grown as a co-culture with CAFs (Continued)

\begin{tabular}{lll}
\hline $64.46 \quad$ LZTR1 & Leucine-zipper-like transcriptional \\
& regulator 1
\end{tabular}

structural constituent of cytoskeleton; DNA binding; chromatin binding; protein binding; small GTPase regulator activity; transcription factor activity

spermatogenesis; immune system process; intracellular protein transport vesicle-mediated transport; cell cycle; nitrogen compound metabolic process; nucleobase, nucleoside, nucleotide and nucleic acid metabolic process; protein metabolic process

\begin{tabular}{lllll}
\hline 65 & 2.46 & OR6V1 & Olfactory receptor 6 V1 & \\
\hline 66 & 2.47 & C12orf65 & Uncharacterized protein C120rf65 & $\begin{array}{l}\text { translation factor activity, nucleic acid } \\
\text { binding; translation release factor } \\
\text { activity }\end{array}$
\end{tabular}

protein metabolic process activity

\begin{tabular}{llll}
\hline 67 & 2.47 & C2orf56 & $\begin{array}{l}\text { Protein midA homolog, } \\
\text { mitochondrial }\end{array}$ \\
\hline 68 & 2.47 & RBM42 & RNA-binding protein 42
\end{tabular}

RNA splicing factor activity, transesterification mechanism; DNA binding; RNA binding spermatogenesis; neurological system process; cell cycle; nucleobase, nucleoside, nucleotide and nucleic acid metabolic process; protein metabolic process; ectoderm development; nervous system development

\begin{tabular}{llll}
\hline 69 & 2.48 & DPM2 & $\begin{array}{l}\text { Dolichol phosphate-mannose } \\
\text { biosynthesis regulatory protein }\end{array}$ \\
\hline 70 & 2.48 & TDRD12 & $\begin{array}{l}\text { Tudor domain-containing protein } \\
12\end{array}$
\end{tabular}

RNA helicase activity; translation factor activity, nucleic acid binding; translation initiation factor activity

nucleobase, nucleoside, nucleotide and nucleic acid metabolic process; protein metabolic process

\begin{tabular}{|c|c|c|c|c|}
\hline 71 & 2.53 & CCDC85B & $\begin{array}{l}\text { Coiled-coil domain-containing } \\
\text { protein } 85 \mathrm{~B}\end{array}$ & \\
\hline 72 & 2.54 & MATN1 & Cartilage matrix protein & extracellular matrix structural constituent \\
\hline
\end{tabular}

immune system process; sensory perception of sound;sensory perception; signal transduction; cell-cell adhesion; cellular component morphogenesis; mesoderm development; skeletal system development; blood coagulation

\begin{tabular}{|c|c|c|c|c|c|}
\hline 73 & 2.55 & FLYWCH1 & $\begin{array}{l}\text { FLYWCH-type zinc finger-containing } \\
\text { protein } 1\end{array}$ & & \\
\hline 74 & 2.55 & PLA2G2D & $\begin{array}{l}\text { Group IID secretory phospholipase } \\
\text { A2 }\end{array}$ & hydrolase activity, acting on ester bonds & $\begin{array}{l}\text { signal transduction; lipid metabolic } \\
\text { process; signal transduction }\end{array}$ \\
\hline 75 & 2.56 & TMEM38A & $\begin{array}{l}\text { Trimeric intracellular cation channel } \\
\text { type A }\end{array}$ & & \\
\hline 76 & 2.58 & RGS11 & Regulator of G-protein signaling 11 & $\begin{array}{l}\text { protein binding;small GTPase regulator } \\
\text { activity }\end{array}$ & $\begin{array}{l}\text { cell surface receptor linked signal } \\
\text { transduction; signal transduction; dorsal/ } \\
\text { ventral axis specification }\end{array}$ \\
\hline 77 & 2.61 & BAHD1 & $\begin{array}{l}\text { Bromo adjacent homology domain- } \\
\text { containing } 1 \text { protein }\end{array}$ & DNA binding & $\begin{array}{l}\text { nucleobase, nucleoside, nucleotide and } \\
\text { nucleic acid metabolic process }\end{array}$ \\
\hline 78 & 2.67 & CHD5 & $\begin{array}{l}\text { Chromodomain-helicase-DNA- } \\
\text { binding protein } 5\end{array}$ & $\begin{array}{l}\text { DNA helicase activity; nucleic acid } \\
\text { binding }\end{array}$ & $\begin{array}{l}\text { nucleobase, nucleoside, nucleotide and } \\
\text { nucleic acid metabolic process; organelle } \\
\text { organization; establishment or } \\
\text { maintenance of chromatin architecture }\end{array}$ \\
\hline 79 & 2.67 & CHD5 & Tryptophan-rich protein; & $\begin{array}{l}\text { structural constituent of ribosome; } \\
\text { nucleic acid binding }\end{array}$ & protein metabolic process \\
\hline 80 & 2.67 & CYP39A1 & Cytochrome P450 39A1 & oxidoreductase activity & $\begin{array}{l}\text { respiratory electron transport chain; lipid } \\
\text { metabolic process }\end{array}$ \\
\hline 81 & 2.68 & SUDS3 & $\begin{array}{l}\text { Sin3 histone deacetylase } \\
\text { corepressor complex component } \\
\text { SDS3 }\end{array}$ & & cell cycle \\
\hline 82 & 2.69 & C16orf62 & UPF0505 protein C16orf62 & & \\
\hline 83 & 2.69 & FLOT2 & Flotillin-2 & & $\begin{array}{l}\text { intracellular protein transport; vesicle- } \\
\text { mediated transport }\end{array}$ \\
\hline
\end{tabular}


Table 3 Down-regulated genes in cancer cells grown as a co-culture with CAFs (Continued)

$84 \quad 2.69 \quad$ NINJ1 Ninjurin-1
adhesion; cell adhesion; ectoderm development; nervous system development

\begin{tabular}{|c|c|c|c|c|}
\hline 85 & 2.70 & FAM84A & Protein FAM84A & \\
\hline 86 & 2.71 & PAF1 & $\begin{array}{l}\text { RNA polymerase II-associated factor } \\
1 \text { homolog }\end{array}$ & \\
\hline 87 & 2.71 & PAF1 & Peroxisome assembly factor 1 & protein metabolic process \\
\hline 88 & 2.77 & POLR2F & $\begin{array}{ll}\text { DNA-directed RNA polymerases I, II, } & \text { DNA-directed RNA polymerase activity; } \\
\text { and III subunit } & \text { nucleic acid binding }\end{array}$ & $\begin{array}{l}\text { nucleobase, nucleoside, nucleotide and } \\
\text { nucleic acid metabolic process }\end{array}$ \\
\hline
\end{tabular}

\begin{tabular}{lllll}
\hline 89 & 2.78 & C12orf34 & Uncharacterized protein C12orf34 & \\
\hline 90 & 2.80 & GGT6 & $\begin{array}{l}\text { Gamma-glutamyltransferase } 6 \text { light } \\
\text { chain }\end{array}$ & acyltransferase activity; peptidase activity
\end{tabular}

\begin{tabular}{|c|c|c|c|c|c|}
\hline & & & & & 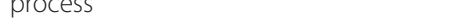 \\
\hline 91 & 2.83 & TSC22D4 & TSC22 domain family protein 4 & DNA binding; transcription factor activity & $\begin{array}{l}\text { nucleobase, nucleoside, nucleotide and } \\
\text { nucleic acid metabolic process }\end{array}$ \\
\hline
\end{tabular}

\begin{tabular}{llllll}
\hline 92 & 2.84 & CLRN2 & Clarin-2 & & \\
\hline 93 & 2.92 & KCNS1 & $\begin{array}{l}\text { Potassium voltage-gated channel } \\
\text { subfamily S member } 1\end{array}$ & $\begin{array}{l}\text { cation transmembrane transporter } \\
\text { activity; voltage-gated potassium } \\
\text { channel activity; cation channel activity }\end{array}$ & $\begin{array}{l}\text { muscle contraction; blood circulation; } \\
\text { neuronal action potential propagation; } \\
\text { cation transport; signal transduction; } \\
\text { synaptic transmission; signal } \\
\text { transduction; cell-cell signaling }\end{array}$ \\
\hline
\end{tabular}

\begin{tabular}{|c|c|c|c|c|c|}
\hline 94 & 2.94 & OR51T1 & Olfactory receptor $51 \mathrm{~T} 1$ & & \\
\hline 95 & 2.96 & OR5111 & Olfactory receptor 5111 & & \\
\hline 96 & 3.01 & ZNF135 & Zinc finger protein 135 & DNA binding;transcription factor activity & $\begin{array}{l}\text { nucleobase, nucleoside, nucleotide and } \\
\text { nucleic acid metabolic process }\end{array}$ \\
\hline 97 & 3.03 & QDPR & Dihydropteridine reductase & oxidoreductase activity & $\begin{array}{l}\text { cellular amino acid and derivative } \\
\text { metabolic process }\end{array}$ \\
\hline 98 & 3.11 & C9 & Complement component $\mathrm{C} 9 \mathrm{~b}$ & peptidase activity; receptor activity & $\begin{array}{l}\text { complement activation; signal } \\
\text { transduction; cell-cell adhesion; protein } \\
\text { metabolic process; signal transduction; } \\
\text { response to stimulus }\end{array}$ \\
\hline 99 & 3.16 & VDAC1 & $\begin{array}{l}\text { Voltage-dependent anion-selective } \\
\text { channel protein } 1\end{array}$ & $\begin{array}{l}\text { voltage-gated ion channel activity; anion } \\
\text { channel activity }\end{array}$ & anion transport \\
\hline 100 & 3.85 & FDX1L & $\begin{array}{l}\text { Adrenodoxin-like protein, } \\
\text { mitochondrial }\end{array}$ & oxidoreductase activity & $\begin{array}{l}\text { respiratory electron transport chain; } \\
\text { ferredoxin metabolic process; vitamin } \\
\text { metabolic process; lipid metabolic } \\
\text { process; protein metabolic process }\end{array}$ \\
\hline
\end{tabular}

The list of down-regulated genes in cancer cells grown as a co-culture with carcinoma-associated fibroblasts (CAFs). Gene ID, name, molecular function and biological process are listed according to the Panther Database classification www.pantherdb.org. The analyzed genes were significantly down-regulated at the level of $p<0.05$, fold change $>2.0$.

observations and those of Swanson et al. [47], we suppose that the MAG up-regulation in cancer cells grown with the CAFs and its binding to the MUC1 may contribute to the adhesion between tumour cells and Schwann cells promoting metastasis to the nervous system.

We also found a down-regulation of 5 key genes associated with adhesion. Subject literature suggests 3 of them play a role in cancer development. The down-regulation of these genes is associated with poor prognosis and cancer metastases. One of these genes is the ADAMTS15 (a disintegrin and metalloproteinase with thrombospondin motif 15) which is an anti-angiogenic factor [48]. Our study also revealed a down-regulation of the CADM4. Nagata et al. [49] found decrease in the
CADM4 expression in most of renal cell carcinomas and the cancer cell lines. Moreover, the CADM4 expression was decreased in carcinomas with vascular infiltration, suggesting that loss of the CADM4 is involved in tumour angiogenesis and invasion. We have also found a down-regulation of the MATN1 gene which has been defined an angiogenesis inhibitor [50].

In the current study we showed a significant overmanifestation of genes involved in the oxytocin receptor mediated signaling pathway, the thyrotropin-releasing hormone receptor signaling, the Beta 2 and Betal adrenergic receptor signaling, and the histamine $\mathrm{H} 1$ receptor mediated signaling in cancer cells grown with the CAFs. Entschladen et al. [51] described the role of 


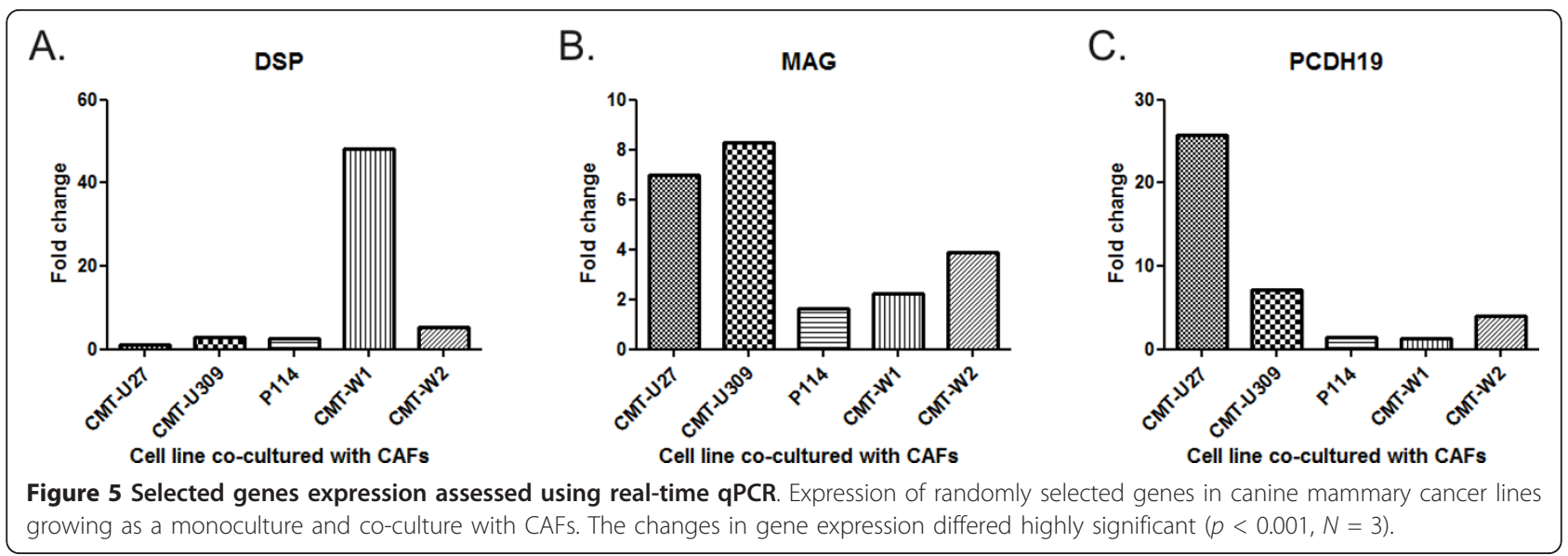

neurotransmitters in cancer progression and metastasis. They found that similarly to chemokines, neurotransmitters are regulators of cell migration. Sadly though, we noticed that only a few results are available on the expression of neurotransmitter receptors in tumour tissues. Among them the best understood is the role of catecholamines in carcinogenesis and tumour progression. These are the stress hormones, whereas stress in turn is a major risk factor for the development of cancer. Norepinephrine has been shown to strongly induce the migration of tumor cells $[52,53]$, whereas epinephrine was found a modulator for the carcinogenesis in the lung [54].
An interesting gene in cancer cells grown as a co-culture with the CAFs is the up-regulated protocadherin 19 (PCDH19) (Table 2). Up-to-date there is no information available on the involvement of this gene in tumor progression or metastasis. However, a PCDH19 mutation was found to be responsible for epilepsy and mental retardation confined to females (EFMR) [55]. There has been an on-going debate about the relationship between epilepsy and cancer. It has been hypothesized that the incidence of cancer is increased in people with epilepsy owing to the cancer promotion by antiepileptic drugs [56]. Perhaps the increased risk of cancer in epileptic patients is caused by the PCDH19 mutation and over-

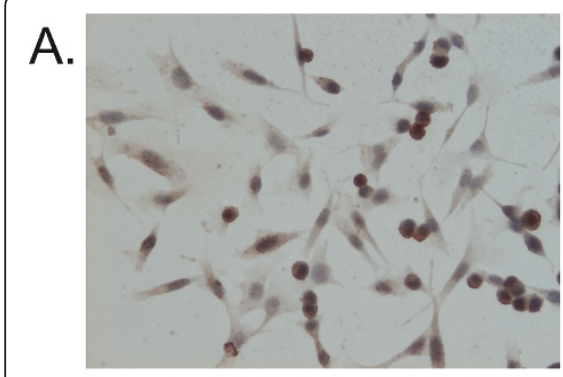

B.
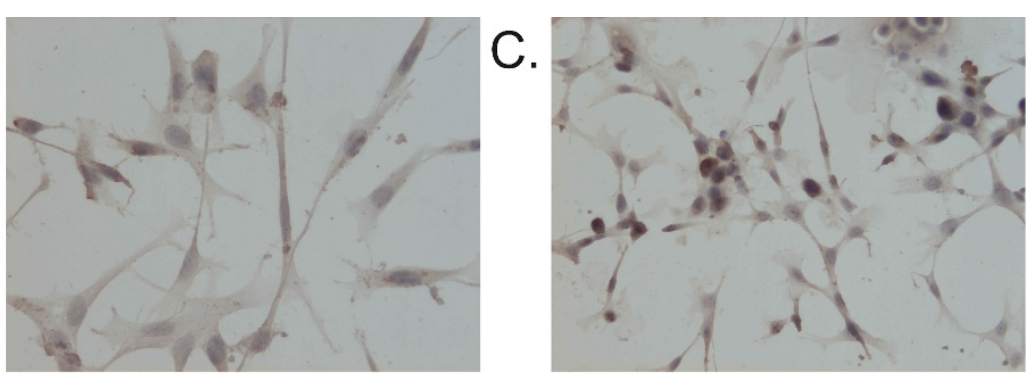

D.

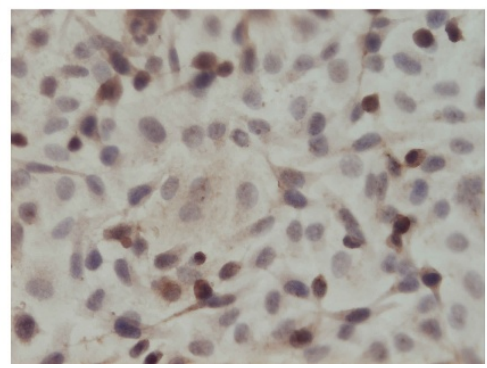

E.

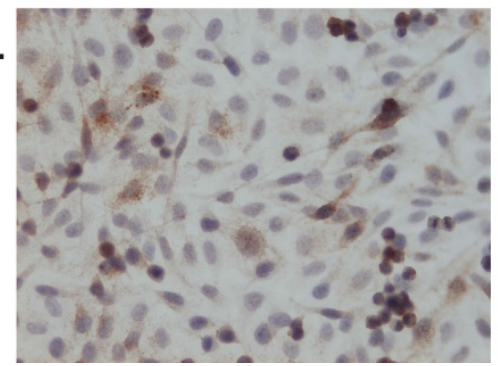

Figure 6 MUC1 expression in canine mammary cancer cell lines. MUC1 expression (brown color) in canine mammary cancer cell lines: A. CMT-U27, B. CMT-U309, C. P114, D. CMT-W1 and E. CMT-W2. The pictures were obtained using Olympus BX60 microscope (at the magnification of $200 \times)$. 
expression, not however related to drugs toxicity. This hypothesis requires further studies.

\section{Conclusions}

The results of the current study showed that the co-culture of cancer cells and the CAFs caused significant changes in expression of genes involved in adhesion, angiogenesis and the EMT that take part in developmental processes.

\section{Acknowledgements}

This work was supported by grant no N N308012939 from Ministry of Sciences and Higher Education. This work was performed by financial support of the Foundation for Polish Science (Start stipendium and ParentBridge program). The authors would like to thank Dr. Małgorzata Gajewska for the confocal analysis and Dr. Alicja Majewska for Bioanalyzer analysis.

\section{Author details}

'Department of Physiological Sciences, Faculty of Veterinary Medicine, Warsaw University of Life Sciences - WULS, Nowoursynowska 159, 02-776 Warsaw, Poland. ${ }^{2}$ Department of Animal Environment Biology, Faculty of Animal Sciences, Warsaw University of Life Sciences - WULS, Ciszewskiego 8, 02-786 Warsaw, Poland. ${ }^{3}$ Institute of Computer Engineering, Control and Robotics 1-6, Wroclaw University of Technology, Wybrzeże Wyspiańskiego 27, 50-320 Wroclaw, Poland. ${ }^{4}$ Department of Pathology and Veterinary Diagnostics, Faculty of Veterinary Medicine, Warsaw University of Life Sciences - WULS, Nowoursynowska 159, 02-776 Warsaw, Poland. ${ }^{5}$ Area Diagnostica Integrata Istologia e Microscopia Elettronica Istituto Zooprofilattico Sperimentale dell'Umbria e delle Marche, Via G. Salvemini 1, 06126 Perugia, Italy.

\section{Authors' contributions}

MK: research design, experimental design, FACS cell sorting, CAFs isolation, manuscript and figures preparation; KP: cell culturing, CAFs isolation, RNA isolation, microarray analyses; KS: real-time GPCR; HM statistical analysis of microarray experiment; ID: histopathological examination of tumour sample and CAFs; EM: immunohistochemical examination; MJ: microarray analysis; TM: manuscript preparation. All authors read and approved the final manuscript.

\section{Competing interests}

The authors declare that they have no competing interests.

Received: 26 September 2011 Accepted: 27 March 2012

Published: 27 March 2012

\section{References}

1. Król M, Pawłowski KM, Dolka I, Musielak O, Majchrzak K, Mucha J, Motyl T: Density of Gr1-positive myeloid precursor cells, p-STAT3 expression and gene expression pattern in canine mammary cancer metastasis. Vet Res Comm 2011, 35:409-423.

2. Król M, Pawłowski KM, Majchrzak K, Dolka I, Abramowicz A, Szyszko K, Motyl T: Density of tumor-associated macrophages (TAMs) and expression of their growth factor receptor MCSF-R and CD14 in canine mammary adenocarcinomas of various grade of malignancy and metastasis. Pol J Vet Sci 2011, 14:3-10.

3. Olumi AF, Grossfeld GD, Hayward SW, Carroll PR, Tlsty TD, Cunha GR: Carcinoma-associated fibroblasts direct tumor progression of initiated human prostatic epithelium. Cancer Res 1999, 59:5002-5011.

4. Lindblom A, Liljegren A: Tumour markers in malignancies. Clin Rev 2000, 320:424-427.

5. Gama A, Alves A, Schmitt F: Identification of molecular phenotypes in canine mammary carcinomas with clinical implications: application of the human classification. Virchows Archiv 1998, 453(2):123-132.

6. Uva P, Aurisicchio L, Watters J, Loboda A, Kulkarni A, Castle J, Palombo F, Viti V, Mesiti G, Zappulli V, Marconato L, Abramo F, Ciliberto G, Lahm A, La
Monica N, Rinaldis E: Comparative expression pathway analysis of human and canine mammary tumors. BMC Genomics 2009, 10:135.

7. Sassi F, Benazzi C, Castellano G, Sarli G: Molecular-based tumour subtypes of canine mammary carcinomas assessed by immunohistochemistry. BMC Vet Res 2010, 6:5.

8. Rao NAS, Wolferen van ME, Gracanin A, Bhatti SFM, Krol M, Holstege FC, Mol JA: Gene expression profiles of progestin-induced canine mammary hyperplasia and spontaneous mammary tumors. J Physiol Pharmacol 2009, 60:73-84.

9. Król M, Pawłowski KM, Skierski J, Rao NAS, Hellmen E, Mol JA, Motyl T: Transcriptomic profile of two canine mammary cancer cell lines with different proliferative and anti-apoptotic potential. J Physiol Pharmacol 2009, 60:95-106.

10. Król M, Pawłowski KM, Skierski J, Turowski P, Majewska A, Polańska J, Ugorski M, Morty RE, Motyl T: Transcriptomic "portraits" of canine mammary cancer cell lines with various phenotype. J Appl Genet 2010, 51:169-183.

11. Król M, Polańska J, Pawłowski KM, Skierski J, Majewska A, Ugorski M, Motyl T: Molecular signature of cell lines isolated from mammary adenocarcinoma metastases to lungs. J Appl Genet 2010, 51:37-50.

12. Pawłowski KM, Popielarz D, Szyszko K, Motyl T, Król M: Growth Hormone Receptor RNA interference decreases proliferation and enhances apoptosis in canine mammary carcinoma cell line CMT-U27. Vet Comp Oncol 2011, 10:2-15.

13. Pawłowski KM, Król M, Majewska A, Badowska-Kozakiewicz A, Mol JA, Malicka E, Motyl T: Comparison of cellular and tissue transcriptional profiles in canine mammary tumor. J Physiol Pharmacol 2009, 60:85-94

14. Limon J, Dal Cin P, Sandberg AA: Application of long-term collagenase disaggregation for the cytogenic analysis of human solid tumors. Cancer Genet Cytogenet 1986, 23(4):305-313.

15. Misdorp W, Else RW, Hellemen A, Lipscomb TP: Histological classification of mammary tumors of the dog and cat. Armed Forces Inst Pathol 1999, 7:11-29.

16. Misdorp W: Tumors of the mammary gland. In Tumours in domestic animals.. 4 edition. Edited by: Meuten DJ. lowa: lowa State Press; 2002:575-606.

17. Tyan SW, Kuo WH, Huang CK, Pan CC, Shew JY, Chang KJ, Lee EYHP, Lee WH: Breast cancer cells induce cancer-associated fibroblasts to secrete hepatocyte growth factor to enhance breast tumorigenesis. PLOS One 2011, 6(1):e15313.

18. Rodriguez LG, Wu X, Guan JL: Wound-healing assay. Methods Mol Biol 2005, 294:23-29

19. Brinkhof B, Spee B, Rothuizen J, Penning LC: Development and evaluation of canine reference genes for accurate quantification of gene expression. Anal Biochem 2006, 356:36-43.

20. Etschmann B, Wilcken B, Stoevesand K, von der Schulenburg A, SternerKock A: Selection of reference genes for quantitative real-time PCR analysis in canine mammary tumors using the GeNorm algorithm. Vet Pathol 2006, 43:934-942.

21. Schmittgen TD, Livak KJ: Analyzing real-time PCR data by the comparative Ct method. Nature Prot 2008, 3:1101-1108.

22. Smyth GK: Linear models and empirical Bayes methods for assessing differential expression in microarray experiments. Stat Appl Genet Mol Biol 2004, 3(1):Article3.

23. Mi H, Lazareva-Ulitsky B, Loo R, Kejariwal A, Vandergriff J, Rabkin S, Guo N, Muruganujan A, Doremieux O, Campbell MJ, Kitano H, Thomas PD: The PANTHER database of protein families, subfamilies, functions and pathways. Nucleic Acids Res 2005, 33:D284-288.

24. Tabiasco J, Vercellone A, Meggetto F, Hudrisier D, Brousset P, Fournie JJ: Acquisition of viral receptor by NK cells through immunological synapse. J Immunol 2003, 170:5993-5998.

25. Olumi A, Dazin P, TIsty TD: A novel coculture technique demonstrates that normal human prostatic fibroblasts contribute to tumor formation of LNCaP cells by retarding cell death. Cancer Res 1998, 58:4525-4530.

26. Basset $P$, Bellocq JP, Wolf $C$, Stoll I, Hutin P, Limacher JM, Podhajcer OL, Chenard MP, Rio MC, Chambon P: A novel metalloproteinase gene specifically expressed in stromal cells of breast carcinomas. Nature 1990 248:699-704.

27. Singer C, Rasmussen A, Smith HS, Lippman ME, Lynch HT, Cullen K: Malignant breast epithelium selects for insulin-like growth factor II 
expression in breast stroma: evidence for paracrine function. Cancer Res 1995, 55:2448-2454.

28. Wright JH, McDonnell S, Portella G, Bowden GT, Balmain A, Matrisian LM: A switch from stromal to tumor cell expression of stromelysin-1 mRNA associated with the conversion of squamous to spindle carcinomas during mouse skin tumor progression. Mol Carcinog 1994, 10:207-215.

29. Mishra P, Banerjee D, Ben-Baruch A: Chemokines at the crossroads of tumor-fibroblast interactions that promote malignancy. J Leuk Biol 2011, 89:31-39.

30. Samoszuk M, Tan J, Chorn G: Clonogenic growth of human breast cancer cells co-cultured in direct contact with serum-activated fibroblasts. Brest Cancer Res 2005, 7:R274-283.

31. Suzuki S, Sato M, Senoo H, Ishikawa K: Direct cell-cell interaction enhances pro-MMP2 production and activation in co-culture of laryngeal cancer cells and fibroblasts: involvement of EMMPRI and MT1-MMP. Exp Cell Res 2004, 293(2):259-266.

32. He Y, Liu X, Chen Z, Zhu J, Xiong Y, Li K, Dong J, Li X: Interaction between cancer cells and stromal fibroblasts is required for activation of the UPAR-UPA-MMP-2 cascade in pancreatic cancer metastasis. Clin Cancer Res 2007, 13:3115-3124.

33. Wernet N, Kaminski A, Haddouti el-M, Hahne JC: Tumor-stroma interactions of metastatic prostate cancer cell lines: analyses using microarrays. Methods Mol Biol 2007, 382:223-237.

34. Sato N, Maehara N, Goggins M: Gene expression profiling of tumorstromal interactions between pancreatic cancer cells and stromal fibroblasts. Cancer Res 2004, 64:6950-6956.

35. Santos RPC, Benvenuti TT, Honda ST, Del Valle PR, Katayama MLH Brentani HP, Carraro DM, Rozenchan PB, Brentani MM, de Lyra EC, Torres CH, Salzgeber MB, Kaiano JHL, Gotes JCS, Folgueira MAAK: Influence of the interaction between nodal fibroblast and breast cancer cells on gene expression. Tumour Biol 2011, 32(1):145-157.

36. Rozencham PB, Carraro DM, Brentani H, de Carvalho Mota LD, Bastos EP, e Ferreira EN, Torres CH, Katayama ML, Roeala RA, Lyra EC, Soares FA, Folgueira MA, Goes JC, Brentani MM: Reciprocal changes in gene expression profiles of cocultured breast epithelial cells and primary fibroblasts. Int I Cancer 2009, 125(12):2767-2777.

37. Ding YB, Chen GY, Xia JG, Zang XW, Yang HY, Yang L: Association of VCAM-1 overexpression with oncogenesis, tumor angiogenesis and metastasis of gastric carcinoma. World I Gastroenterol 2003, 9(7):1409-1414.

38. Shin J, Kim J, Ryu B, Chi SG, Park H: Caveolin-1 is associated with VCAM-1 dependent adhesion of gastric cancer cells to endothelial cells. Cell Physiol Biochem 2006, 17:211-220.

39. Zhou X, Stuart A, Dettin LE, Rodriguez G, Hoel B, Gallicano Gl: Desmoplakin is required for microvascular tube formation in culture. J Cell Sci 2004 117:3129-3140.

40. Chidgey M, Dawson C: Desmosomes: a role in cancer? Brit J Canc 2007. 96:1783-1787

41. Papagerakis S, Shabana AH, Pollock BH, Papagerakis P, Depondt J, Berdal A: Altered desmoplakin expression at transcriptional and protein levels provides prognostic information in human oropharyngeal cancer. Hum Pathol 2009, 40(9):1320-1329.

42. Qiao Y, Jiang X, Lee ST, Karuturi RK, Hooi SC, Yu Q: FOXQ1 regulates epithelial-mesenchymal transition in human cancers. Cancer Res 2011, 71:3076

43. Fuerborn A, Srivastava PK, Kuffer S, Grandy WA, Sijmonsma TP, Gretz N, Brors B, Grone HJ: The Forkhead factor FoxQ1 influences epithelial differentiation. J Cell Physiol 2011, 226:710-719.

44. Kaneda H, Arao T, Tanaka K, Tamura D, Aomatsu K, Kudo K, Sakai K, de Velasco MA, Matsumoto K, Fajita Y, Yamada Y, Tsurutani J, Okamoto I, Nakagawa K, Nishio K: FOXQ1 is overexpressed in colorectal cancer and enhances tumorigenicity and tumor growth. Cancer Res 2010, 70:2053-2063.

45. Harless WW: Cancer treatments transform residual cancer cell phenotype. Canc Cell Internat 2011, 11:1.

46. Savanger P: The epithelial-mesenchymal transition (EMT) phenomenon. Annals of Oncol 2010, 21:vii89-vii92.

47. Swanson BJ, McDermott KM, Singh PK, Eggers JP, Crocker PR, Hollingsworth MA: MUC1 is a counter-receptor for myelin-associated glycoprotein (Siglec-4a) and their interaction contributes to adhesion in pancreatic cancer perineural invasion. Cancer Res 2007, 67:10222-10229.
48. Wagstaff L, Kelwick R, Decock J, Arnold H, Pennington C, Jaworkki D, Edwards D: ADAMTS15 metalloproteinase inhibits breast cancer cell migration. Breast Cancer Res 2010, 12:P15.

49. Nagata M, Sakurai-Yageta M, Yamada D, Goto A, Ito A, Fukuhara H, Kume H, Morikawa T, Fukayama M, Homma Y, Murakami Y: Aberrations of a cell adhesion molecule CADM4 in renal clear cell carcinoma. Int J Cancer 2011, doi:10.1002/ijc.26160

50. Foradori MJ, Chen Q, Tsang PCW, Langer R, Moses MA: Matrilin-1: a novel potential regulator of angiogenesis. Proc Amer Assoc Cancer Res 2006, 47:2806.

51. Entschladen F, Drell TL IV, Lang K, Joseph J, Zaenker KS: Neurotrasmitters and chemokines regulate tumor cell migration: potential for a new pharmacological approach to inhibit invasion and metastasis development. Curr Pharmaceutical Design 2005, 11:403-411.

52. Drell TL, Joseph J, Lang K, Niggemann B, Zaenker KS, Entschladen F: Effects of neurotransmitters on the chemokinesis and chemotaxis of MDS-MB468 human breast carcinoma cells. Breast Cancer Res Treat 2003, 80:63-70.

53. Masur K, Niggemann B, Zanker KS, Entschladen F: Norepinefrine-induced migration of SW 480 colon carcinoma cells is inhibited by beta-blockers. Cancer Res 2001, 61:2866-2869.

54. Schuller HM, Porter B, Riechert A: Beta-adrenergic modulation of NNKinduced lung carcinogenesis in hamsters. J Cancer Res Clin Oncol 2000 126:624-630.

55. Hynes K, Tarpey P, Dibbens LM, Bayly MA, Berkovic SF, Smith R, Turner SJ, Brown NJ, Desai TD, Haan E, Turner G, Christodoulou J, Leonard H, Gill D, Stratton MR, Gecz J, Scheffer IE: Epilepsy and mental retardation limited to females with PCDH19 mutations can present de novo or single generation families. J Med Genet 2011, 47:211-216.

56. Singh G, Driever PH, Sander JW: Cancer risk in people with epilepsy: the role of antiepileptic drugs. Brain 2005, 128:7-17.

doi:10.1186/1746-6148-8-35

Cite this article as: Król et al:: The gene expression profiles of canine mammary cancer cells grown with carcinoma-associated fibroblasts (CAFs) as a co-culture in vitro. BMC Veterinary Research 2012 8:35.

\section{Submit your next manuscript to BioMed Central and take full advantage of:}

- Convenient online submission

- Thorough peer review

- No space constraints or color figure charges

- Immediate publication on acceptance

- Inclusion in PubMed, CAS, Scopus and Google Scholar

- Research which is freely available for redistribution
C BioMed Central 